\title{
Unequal Cut in Limb Amputations: Diabetes and Health Disparity in the United States
}

\author{
Ucheoma Nwagbara, $\mathrm{PhD}^{1}$ \\ Department of Public Policy, Nelson Mandela College of Government and Social Sciences \\ Southern University and A\&M College, Baton Rouge, Louisiana, USA 70807
}

\begin{abstract}
This paper discusses the diabetes "epidemic" (U.S. Centers for Disease Control and Prevention, [herein after CDC] https://www.cdc.gov/diabetes/library/features/diabetes-stat-report.html) in the United States. Specifically, the paper will discuss the racial disparity in diabetes disease prevalence and impacts between African Americans and Whites in the United States. The disproportionate prevalence, impacts, treatment, and care of diabetes between African Americans and Whites is particularly manifested in the diabetes related lower extremity amputations (LEA) undergone by African Americans compared to their White counterparts pertinent to causal, predisposing, and preventive factors. Through comparative analysis and using diabetic amputation rates, extant LEA encounter studies and data in the literature will be used to analyze and demonstrate "The Black American Amputation Epidemic" with implications for public policy and public health. Methodically, the paper conducted systematic review and meta-analysis of observational studies, government reports, secondary data, PubMed articles, Google Scholar Databases, published references. Consistent with existing empirical literature, the paper find and conclude that African Americans and other racial minorities suffer disproportionate preventable diabetes induced LEAs and deaths compared to Whites, further widening racial health care disparity problem. In addition, the paper adds to the body of knowledge and awareness of the increasing problem of diabetes on the African American population health germane to public policy intervention to reduce, if not totally eliminate the problem. Policy interventions including robust diabetes mitigation policy and leadership in the American health care system, more funding, research, education, better management, and preventive care for all patients at risk of amputation should be pursued, especially focusing on the historically underserved population. In this paper, the terms "Black (s)," "Black Americans," "African Americans," "racial minorities" and "people of color" are used interchangeably.
\end{abstract}

Keywords: Diabetes, race, Black, White, health disparity, amputation, policy, United States

DOI: $10.7176 / \mathrm{JHMN} / 95-10$

Publication date: November $30^{\text {th }} 2021$

\section{Introduction}

Globally, according to the World Health Organization [herein after WHO] the number of people with diabetes increased from 108 million in 1980 to 422 million in 2014, while the prevalence of diabetes among adults over 18 years of age rose from $4.7 \%$ in 1980 to $8.5 \%$ in 2014 (WHO, 2020). In 2016, worldwide, an estimated 1.6 million deaths were directly caused by diabetes, and between 2000 and 2016, there was a 5\% increase in premature mortality from diabetes (WHO, 2020). Aside being the major cause of blindness, kidney failure, heart attacks, stroke and lower limb amputation (WHO, 2020), diabetes exacerbates major infectious diseases such as tuberculosis (TB), malaria and HIV/AIDS (WHO, 2012). People with diabetes are three times more likely to develop TB when infected and approximately $15 \%$ of TB globally is thought to be due to diabetes (WHO, 2012). The economic costs of diabetes is also enormous.

In its "Global Report on Diabetes 2016" the WHO stated: "Diabetes and its complications bring about substantial economic loss to people with diabetes and their families, and to health systems and national economies through direct medical costs and loss of work and wages. While the major cost drivers are hospital and outpatient care, a contributing factor is the rise in cost for analog insulins ${ }^{2}$ which are increasingly prescribed despite little evidence that they provide significant advantages over cheaper human insulins" (p. 6). The United States is not immune to the global diabetes problem.

There are 34.2 million people (10.5\% of the population) in the United States with diabetes (CDC, National Diabetes Statistics Report 2020, p. 2), 88 million with pre-diabetes (34.5\% of the population), and 1.5 million diagnosed new cases of diabetes every year (American Diabetes Association, https://www.diabetes.org/resources/statistics/statistics-about-diabetes). (Table 2). Diabetes is a source of considerable cost to the health care system (Rayman, et al. 2004, p. 1892). In the United States, diabetes and related complications are estimated to result in direct medical costs totaling $\$ 237$ billion, and $\$ 90$ billion of

\footnotetext{
${ }^{1}$ Ucheoma Nwagbara is an Adjunct Professor of Health Policy and Health Sociology at Southern University and A\&M College, Baton Rouge, Louisiana, USA.

${ }^{2}$ These are insulins derived from human insulin by modifying its structure to change the pharmacokinetic profile.
} 
indirect costs due to reduced productivity from disability, absenteeism, and early mortality (American Diabetes Association, 2018). Between 2012 and 2017, excess medical costs per person associated with diabetes increased from $\$ 8,417$ to $\$ 9,601$, or 14\% (CDC, National Diabetes Statistics Report 2020, p. 13). Also, diabetes is a leading cause of death and disability in the United States (Lord, Roberson, \& Odoi, 2020). In fact, diabetesrelated mortality is considered the seventh ("and may be underreported" https://www.cdc.gov/diabetes/basics/quick-facts.html ) leading cause of death in the United States, after stroke and Alzheimer disease (Table 3, Xu et al. 2020; Kochanek et al., 2019). Furthermore, diabetes is the number one cause of kidney failure, lower-limb amputations, and adult blindness in the United States (CDC, https://www.cdc.gov/diabetes/basics/diabetes.html). The African American population and other racial minorities are hardest hit by the diabetes epidemic.

Members of racial and ethnic minority groups in the United States, especially African Americans, suffer disproportionately from many chronic diseases, including diabetes (Signorello et al. 2007; Wong et al. 2002; Carter, Pugh, \& Monterrosa, 1996; Cowie et al., 1989; Herman et al. 2007; Gaskin et al., 2014). At the same time, diabetes-related death is higher for minorities than for Whites, and it is not letting up (Carter, Pugh, \& Monterrosa, 1996; CDC, 2007; Saydah et al., 2017). In addition, diabetes related amputations are done more frequently among African Americans than among Whites (9.0 per 1000 compared with 6.3 per 1000), and Pima Indians have 3.7 times more amputations than do Whites (Carter, Pugh, \& Monterrosa, 1996). More recent studies re-affirm the foregoing with alarming pattern and prevalence. African Americans are more likely to have diabetes than Whites (Margolis, et al., 2011; Ko et al., 2014; Mitin et al., 2011; Gaskin et al., 2014; Link \& McKinlay, 2013; Tan, et al., 2019), high prevalence of gestational diabetes (Sridhar et al., 2016; Hedderson et al., 2012; Nguyen et al., 2012), and obesity and diabetes are highly prevalent in women with Type I and II endometrial cancers, especially in African Americans (Ko, et al., 2014).

How prevalent is diabetes among African Americans? African Americans have the highest prevalence rate of diabetes in the United States at 16.4\% (Table 4). In addition, according to the American Diabetes Association, "Inequity systemically harms people of color...It contributes to worse outcomes and higher risk for diabetes and many other diseases" (https://www.diabetes.org/healthequitynow). The CDC offers a more vivid picture. According to the CDC (Diabetes - https://www.cdc.gov/media/presskits/aahd/diabetes.pdf):

- African Americans are 1.7 times as likely to develop diabetes as whites

- The prevalence of diabetes among blacks has quadrupled during the past 30 years

- Among blacks age 20 and older, about 2.3 million have diabetes - 10.8 percent of that age group

- Blacks with diabetes are more likely than non-Hispanic whites to experience greater disability from diabetes-related complications such as amputations, adult blindness, kidney failure, and increased risk of heart disease and stroke

- $\quad$ Death rates for blacks with diabetes are 27 percent higher than for whites.

Worse, African Americans have the highest diabetes mortality disparity in the United States (Rosenstock et al., 2014). Table 1 show that overall diabetes mortality rate in the United States (2005-2007, 3-year average) was 23.6/100,000 population (Rosenstock et al., 2014, p. 875). When categorized by race, the White diabetes mortality rate was 20.8 and the Black rate was 44.4, giving a rate ratio of 2.13 (95\% Confidence Interval: $2.11-$ 2.16). This study of African American/White racial disparity in diabetes mortality across the 50 most populous cities in the United States is very revealing. Table 1 presents in descending order city-level Black/White diabetes mortality rate ratios for 41 of the 50 most populous cities in the United States. All cities included in this analysis had Black mortality rates above the national average of 23.6. Of the 41 cities analyzed, $32(78 \%)$ had Black mortality rates greater than the highest White mortality rate (Cleveland (34.5), and there were nearly 6,800 annual excess Black diabetes deaths in the United States during the study period. Annual city-level excess Black deaths ranged from 442 in New York City to none in Detroit (-34), while the annual number of excess Black diabetes deaths in these cities accounted for $27 \%$ of all excess Black diabetes deaths in the United States. The 41 cities included in this analysis represent $14 \%$ of the total United States population.

The rest of the paper is organized as follows: Section II deals with diabetes basics (tabular description). Section III discusses determinants of diabetes prevalence. Section IV addresses diabetes amputations and the African American experience. Section V concludes the paper. 
Table 1: Estimates (3-year) of Black/White Diabetes Mortality Disparity in the 50 Most Populous Cities in United States, 2005-2007 (N=41)

\begin{tabular}{|c|c|c|c|c|c|c|c|}
\hline $\begin{array}{l}\text { US cities (in order of } \\
\text { descending Black/ } \\
\text { White diabetes } \\
\text { mortality rate ratio) }\end{array}$ & $\begin{array}{l}\text { Mortality } \\
\text { rate } \\
\text { (any race) }\end{array}$ & $\begin{array}{l}\text { Mortality } \\
\text { rate } \\
\text { White }\end{array}$ & $\begin{array}{l}\text { Mortality } \\
\text { rate } \\
\text { Black }\end{array}$ & $\begin{array}{l}\text { Mortality } \\
\text { rate ratio } \\
\text { Black/ } \\
\text { White }^{\mathrm{a}}\end{array}$ & \multicolumn{2}{|c|}{$95 \% \mathrm{Cl}$} & \multirow{2}{*}{$\begin{array}{l}\text { Annual } \\
\text { excess } \\
\text { Black } \\
\text { deaths } \\
6798.70\end{array}$} \\
\hline United States & 23.64 & 20.79 & 44.38 & 2.13 & 2.11 & 2.16 & \\
\hline Washington, DC & 30.17 & 10.90 & 41.18 & 3.78 & 2.84 & 5.02 & 112.36 \\
\hline San Francisco, CA & 12.53 & 9.39 & 34.04 & 3.62 & 2.65 & 4.96 & 15.33 \\
\hline San Diego, CA & 19.92 & 15.14 & 54.66 & 3.61 & 2.89 & 4.50 & 25.97 \\
\hline Omaha, NE & 28.56 & 23.09 & 82.53 & 3.57 & 2.76 & 4.62 & 19.58 \\
\hline Seattle, WA & 22.54 & 18.83 & 64.82 & 3.44 & 2.64 & 4.49 & 18.51 \\
\hline Phoenix, AZ & 19.38 & 15.18 & 48.93 & 3.22 & 2.45 & 4.25 & 15.09 \\
\hline Dallas, TX & 24.92 & 15.52 & 45.49 & 2.93 & 2.47 & 3.49 & 70.42 \\
\hline New York City, NY & 20.14 & 12.54 & 36.58 & 2.92 & 2.73 & 3.12 & 441.89 \\
\hline Los Angeles, CA & 27.97 & 18.49 & 53.09 & 2.87 & 2.59 & 3.18 & 134.23 \\
\hline Memphis, TN & 35.93 & 19.10 & 52.42 & 2.74 & 2.28 & 3.30 & 93.77 \\
\hline Oakland, CA & 29.37 & 16.65 & 44.66 & 2.68 & 1.94 & 3.70 & 37.20 \\
\hline Kansas City, MO & 25.11 & 17.05 & 45.28 & 2.66 & 2.11 & 3.35 & 32.02 \\
\hline Oklahoma City, OK & 25.58 & 21.91 & 57.32 & 2.62 & 2.06 & 3.32 & 20.55 \\
\hline Arlington, TX & 21.21 & 19.16 & 48.93 & 2.55 & 1.53 & 4.27 & 4.63 \\
\hline Fresno, CA & 39.72 & 28.52 & 72.52 & 2.54 & 1.87 & 3.47 & 10.82 \\
\hline Houston, TX & 28.53 & 18.52 & 46.08 & 2.49 & 2.19 & 2.83 & 113.11 \\
\hline Tulsa, OK & 26.77 & 23.02 & 56.87 & 2.47 & 1.89 & 3.23 & 15.30 \\
\hline Portland, OR & 36.01 & 33.78 & 82.63 & 2.45 & 1.89 & 3.17 & 14.22 \\
\hline Indianapolis, IN & 26.53 & 20.59 & 49.45 & 2.4 & 2.02 & 2.85 & 44.00 \\
\hline Denver, CO & 16.48 & 12.27 & 28.85 & 2.35 & 1.69 & 3.28 & 9.91 \\
\hline Charlotte, NC & 21.84 & 16.25 & 38.1 & 2.34 & 1.86 & 2.96 & 29.17 \\
\hline Wichita, KS & 25.52 & 22.09 & 51.36 & 2.33 & 1.69 & 3.20 & 10.08 \\
\hline Austin, TX & 23.02 & 16.53 & 37.00 & 2.24 & 1.61 & 3.11 & 9.36 \\
\hline Columbus, $\mathrm{OH}$ & 34.03 & 26.53 & 58.52 & 2.21 & 1.86 & 2.62 & 43.39 \\
\hline Minneapolis, MN & 25.69 & 21.42 & 46.69 & 2.18 & 1.55 & 3.06 & 8.50 \\
\hline Long Beach, CA & 25.49 & 21.73 & 47.24 & 2.17 & 1.57 & 3.01 & 9.80 \\
\hline Fort Worth, TX & 32.87 & 26.77 & 57.68 & 2.16 & 1.74 & 2.66 & 26.48 \\
\hline Atlanta, GA & 26.20 & 15.38 & 31.22 & 2.03 & 1.50 & 2.75 & 38.02 \\
\hline San Jose, CA & 28.00 & 25.10 & 50.04 & 1.99 & 1.37 & 2.90 & 6.59 \\
\hline Milwaukee, WI & 27.09 & 20.78 & 40.01 & 1.93 & 1.56 & 2.39 & 27.44 \\
\hline Boston, MA & 19.97 & 17.76 & 32.49 & 1.83 & 1.43 & 2.33 & 16.46 \\
\hline San Antonio, TX & 38.11 & 24.46 & 44.47 & 1.82 & 1.44 & 2.29 & 13.76 \\
\hline Philadelphia, PA & 24.34 & 18.66 & 33.74 & 1.81 & 1.60 & 2.05 & 86.50 \\
\hline Las Vegas, NV & 17.75 & 16.90 & 30.33 & 1.79 & 1.30 & 2.48 & 7.83 \\
\hline Jacksonville, FL & 36.54 & 31.71 & 56.32 & 1.78 & 1.52 & 2.07 & 40.13 \\
\hline Sacramento, CA & 35.84 & 33.99 & 59.18 & 1.74 & 1.36 & 2.23 & 12.94 \\
\hline Virginia Beach, VA & 17.21 & 16.12 & 26.92 & 1.67 & 1.15 & 2.42 & 4.96 \\
\hline Chicago, IL & 27.35 & 20.09 & 33.11 & 1.65 & 1.49 & 1.83 & 126.37 \\
\hline Baltimore, MD & 36.79 & 27.63 & 43.5 & 1.57 & 1.33 & 1.86 & 57.49 \\
\hline Cleveland, $\mathbf{O H}$ & 35.42 & 34.49 & 36.43 & 1.06 & 0.87 & 1.28 & 4.35 \\
\hline Detroit, MI & 32.54 & 33.44 & 29.45 & 0.88 & 0.71 & 1.09 & -34.40 \\
\hline $\begin{array}{l}\text { Nine cities were exce } \\
\text { Jefferson County, and } \mathrm{N} \\
\text { Mesa and Tucson (fewer } \\
{ }^{2} \text { RRs in italics are st. }\end{array}$ & $\begin{array}{l}\text { ed from an } \\
\text { ville/Davids } \\
\text { an } 20 \text { Black } \\
\text { tically signi }\end{array}$ & $\begin{array}{l}\text { es: San Ju } \\
\text { (data not } \\
\text { aths) } \\
\text { nt }\end{array}$ & 10 morta & $\begin{array}{l}\text { ata avail. } \\
\text { Albuquer }\end{array}$ & $\begin{array}{l}\text { Hor } \\
\text { Colo }\end{array}$ & Spri & $\begin{array}{l}\text { ouisville/ } \\
\text { El Paso, }\end{array}$ \\
\hline
\end{tabular}

Source: Adapted from Summer Rosenstock et al (2014), "Racial Disparities in Diabetes Mortality in the 50 Most Populous US Cities." Journal of Urban Health: Bulletin of the New York Academy of Medicine, 91(5), p.876.

https://www.ncbi.nlm.nih.gov/pmc/articles/PMC4199450/pdf/11524_2013_Article_9861.pdf. 
Table 2: United States - Diabetes by the Numbers

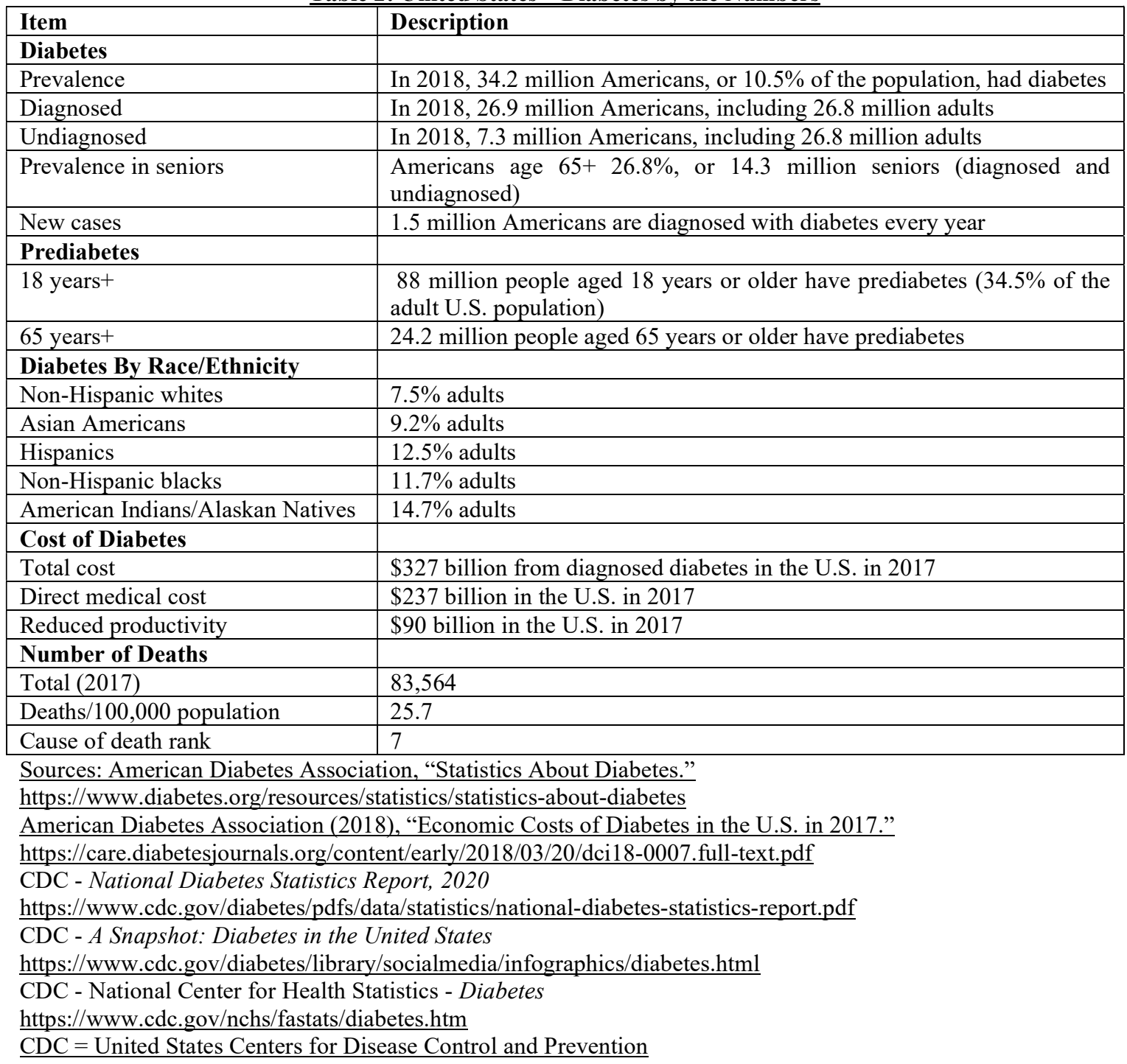


Table 3: United States: 15 Leading Causes of Death for the Total Population 2017

\begin{tabular}{clcc}
\hline Rank & Cause of Death & Number of Deaths & Percent of Total Deaths \\
\hline & All Causes & $2,813,503$ & 100.0 \\
1 & Diseases of heart & 647,457 & 23.0 \\
2 & Malignant neoplasms & 599,108 & 21.3 \\
3 & Accidents (unintentional injuries) & 169,936 & 6.0 \\
4 & Chronic lower respiratory disease & 160,201 & 5.7 \\
5 & Cerebrovascular diseases (e.g. stroke) & 146,383 & 5.2 \\
6 & Alzheimer disease & 121,404 & 4.3 \\
7 & Diabetes Mellitus & 83,564 & 3.0 \\
8 & Influenza and pneumonia & 55,672 & 2.0 \\
9 & Nephritis and nephrosis & 50,633 & 1.8 \\
10 & Suicide (intentional self-harm) & 47,173 & 1.7 \\
11 & Chronic liver disease and cirrhosis & 41,743 & 1.5 \\
12 & Septicemia & 40,922 & 1.5 \\
13 & Hypertension and renal disease & 35,316 & 1.3 \\
14 & Parkinson disease & 31,963 & 1.1 \\
15 & Pneumonitis due to solids and liquids & 20,108 & 0.7 \\
& All other causes & 561,920 & 20.0 \\
\hline
\end{tabular}

Source: Adapted from Kenneth D. Kochanek et al. (June 24, 2019). "Deaths:

Final Data for 2017." U.S. Department of Health and Human Services. Centers for Disease Control and Prevention. National Center for Health Statistics. National Vital Statistics Reports.

https://www.cdc.gov/nchs/data/nvsr/nvsr68/nvsr68 09-508.pdf.

Table 4: Estimated Prevalence of Diagnosed Diabetes, Undiagnosed Diabetes, and Total Diabetes Among Adults Aged 18 Years or Older, United States, 2013-2016

\begin{tabular}{|c|c|c|c|}
\hline Characteristic & $\begin{array}{l}\text { Diagnosed diabetes } \\
\text { Percentage } \\
(95 \% \mathrm{Cl})\end{array}$ & $\begin{array}{l}\text { Undiagnosed diabetes } \\
\text { Percentage } \\
(95 \% \mathrm{CI})\end{array}$ & $\begin{array}{l}\text { Total diabetes } \\
\text { Percentage } \\
(95 \% \mathrm{Cl})\end{array}$ \\
\hline Total & $10.2(9.3-11.2)$ & $2.8(2.4-3.3)$ & $13.0(12.0-14.1)$ \\
\hline \multicolumn{4}{|l|}{ Age in years } \\
\hline $18-44$ & $3.0(2.6-3.6)$ & $1.1(0.7-1.8)$ & $4.2(3.4-5.0)$ \\
\hline $45-64$ & $13.8(12.2-15.6)$ & $3.6(2.8-4.8)$ & $17.5(15.7-19.4)$ \\
\hline$\geq 65$ & $21.4(18.7-24.2)$ & $5.4(4.1-7.1)$ & $26.8(23.7-30.1)$ \\
\hline \multicolumn{4}{|l|}{ Sex } \\
\hline Men & $11.0(9.7-12.4)$ & $3.1(2.3-4.2)$ & $14.0(12.3-15.5)$ \\
\hline Women & $9.5(8.5-10.6)$ & $2.5(2.0-3.2)$ & $12.0(11.0-13.2)$ \\
\hline \multicolumn{4}{|l|}{ Race/ethnicity } \\
\hline White, non-Hispanic & $9.4(8.4-10.5)$ & $2.5(1.9-3.3)$ & $11.9(10.9-13.0)$ \\
\hline Black, non-Hispanic & $13.3(11.9-14.9)$ & $3.0(2.0-4.5)$ & $16.4(14.7-18.2)$ \\
\hline Asian, non-Hispanic & $11.2(9.5-13.3)$ & $4.6(2.8-7.2)$ & $14.9(12.0-18.2)$ \\
\hline Hispanic & $10.3(8.1-13.1)$ & $3.5(2.5-4.8)$ & $14.7(12.5-17.3)$ \\
\hline
\end{tabular}

Source: Adapted from CDC - National Diabetes Statistics Report 2020, p. 2.

https://www.cdc.gov/diabetes/pdfs/data/statistics/national-diabetes-statistics-report.pdf. 


\section{Diabetes Basics}

Table 5: Diabetes, Symptoms, Risk Factors, Complications

\begin{tabular}{|c|c|c|}
\hline What is Diabetes & Diabetes Symptoms & Diabetes Risk Factors \\
\hline $\begin{array}{l}\text { Diabetes is a chronic disease that affects how } \\
\text { the body turns food into energy and uses } \\
\text { blood sugar (glucose). When blood sugar } \\
\text { rises, it prompts the pancreas to release } \\
\text { insulin. Insulin acts like a key to let the blood } \\
\text { sugar into the body cells for use as } \\
\text { energy. With diabetes, your body either } \\
\text { doesn't make enough insulin or can't use it } \\
\text { as well as it should. }\end{array}$ & $\begin{array}{l}\text { Increased thirst, frequent urination, extreme } \\
\text { hunger, unexplained weight loss, fatique } \\
\text { (feel very tired), irritability, blurred vision, } \\
\text { slow-healing sores, frequent infections. }\end{array}$ & $\begin{array}{l}\text { Family history, age, overweight, inactivity, } \\
\text { race or ethnicity, high blood pressure, } \\
\text { environmental factors, geography. }\end{array}$ \\
\hline Types of Diabetes & Complications & Diabetes Tests \\
\hline $\begin{array}{l}\text { There are Type 1, Type 2, and gestational } \\
\text { diabetes. With Type } 1 \text { diabetes, the body } \\
\text { immune system which normally fights } \\
\text { harmful bacteria or viruses, attacks and } \\
\text { destroys the insulin-producing cells in the } \\
\text { pancreas. This leaves your body with little or } \\
\text { no insulin. Instead of being transported into } \\
\text { your cells, sugar builds up in your } \\
\text { bloodstream. With Type } 2 \text { diabetes your cells } \\
\text { become resistant to the action of insulin, and } \\
\text { your pancreas is unable to make enough } \\
\text { insulin to overcome this resistance. Instead } \\
\text { of moving into your cells where it's needed } \\
\text { for energy, sugar builds up in your } \\
\text { bloodstream. Gestational diabetes is } \\
\text { pregnancy related. It occurs when the body } \\
\text { cannot make enough insulin during } \\
\text { pregnancy. }\end{array}$ & $\begin{array}{l}\text { If you are diabetic you are more likely to } \\
\text { have: cardiovascular diseases (e.g. heart } \\
\text { attack, coronary artery disease with chest } \\
\text { pain, stroke and narrowing of arteries); nerve } \\
\text { damage (neuropathy - if left untreated could } \\
\text { cause loss of feelings in limbs, for men it may } \\
\text { lead to erectile dysfunction); kidney damage } \\
\text { (nephropathy - can lead to kidney failure or } \\
\text { permanent end-stage kidney disease, which } \\
\text { may require dialysis or kidney transplant); } \\
\text { eye damage (retinopathy - can cause } \\
\text { cataracts and glycoma, and potentially lead } \\
\text { to blindness); foot damage (nerve damage in } \\
\text { the feet can cause infections to heal poorly, } \\
\text { and if left unreated can lead to toe, foot, or } \\
\text { leg amputation; hearing impairment (more } \\
\text { common in people with diabetes); } \\
\text { Alzeimers's disease (diabetes may increase } \\
\text { the risk of dementia). }\end{array}$ & $\begin{array}{l}\text { A1C Test (hemoglobin A1C or HBA1c test) } \\
\text { measures your average blood sugar level } \\
\text { over the past } 2 \text { or } 3 \text { months. An A1C below } \\
5.7 \% \text { is normal, between } 5.7 \text { and } 6.4 \% \\
\text { indicates you have prediabetes, and } 6.5 \% \text { or } \\
\text { higher indicates you have diabetes. }\end{array}$ \\
\hline
\end{tabular}

Sources: CDC, Diabetes Basics https://www.cdc.gov/diabetes/basics/index.html

CDC, Diabetes Tests https://www.cdc.gov/diabetes/basics/getting-tested.html

Mayo Clinic, Diabetes

https://www.mayoclinic.org/diseases-conditions/diabetes/symptoms-causes/syc-20371444

\section{Determinants of Diabetes Prevalence}

While the reasons for racial disparities in diabetes prevalence are not clear, or "not well understood" (Golden et al. 2019), it has been suggested that behavioral, environmental, socioeconomic, physiological, and family history are risk factors (Signorello et al., 2007; Harris, 1990; Cowie et al., 1993; Harris et al., 1998; Carter, Pugh, \& Monterrosa, 1996). These risk factors are collectively referred to as social determinants of health. For the sake of space and brevity, four risk factors of diabetes will be discussed beginning with socioeconomic factor, followed by obesity, environment, and discrimination.

\section{A. Socioeconomic Status}

Several studies have found that socioeconomic status is not only strongly correlated with diabetes, but also, diabetes is more prevalent in deprived and depressed minority areas (Link \& McKinlay, 2009; Lord, Roberson, \& Odoi, 2020; Connolly et al., 2000; Rabi et al., 2006; Jamil et al., 2008; Cunningham et al., 2008; Signorello et al., 2007). Wachtel (2005, p. 334) "family poverty accounts for differences in lower-extremity amputation rates of minorities." One study (Link \& McKinlay, 2009), for example, in the Boston Area Community Health (BACH) epidemiology based survey of 5,503 Boston (in the State of Massachusetts, United States) residents aged 30-79 (1,767 Black, 1,877 Hispanic, 1,859 White; 2,301 men and 3,202 women), on socioeconomic status (education and income) covariate, found that "Blacks and Hispanics have statistically significantly increased odds of having diabetes compared to Whites:" Blacks (12.8\%), Hispanics (11.6\%), and Whites (7.5\%). Also, a 2020 study in the State of Florida, United States, based on the state's Behavioral Risk Factor Surveillance System respondents found that "disparities of pre-diabetes and diabetes exist in Florida" but most importantly "income level is a significant predictor of diabetes" (Lord, Roberson, \& Odoi, 2013). Another study (Marley \& Metzger, 2015) concluded that the "higher rates of obesity and type 2 diabetes in the American Indian young 
adults than in the general U.S. population can be partially explained by neighborhood poverty" and economic "stress." Piccolo et al. (2014) found "it is likely that non-genetic factors, specifically socioeconomic factors, account for much of the reported racial/ethnic disparities in type 2 diabetes mellitus (T2DM) incidence" and "childhood obesity overweight prevalence" ( Stamatakis \& Cole, 2010).

Butler (2017) investigation concluded "low family income and parental education....are common negative social determinants of health (SDOH) among families of youth with type 2 diabetes mellitus (T2DM)." Piccolo et al. (2016) study of "joint contributions of competing risk factors for T2DM" found that "socioeconomic factors had the greatest impact on explaining the excess prevalence of T2DM among racial/ethnic minorities." In addition, in a study of the "50 most populous US cities," Rosenstock et al (2014, p. 883) found that "nearly $75 \%$ of the disparity in diabetes mortality rates between African Americans and Whites was explained by economic inequality and segregation." The WHO summarized it neatly in its "Global Report on Diabetes 2016" (p.4): ..."diabetes and its complications impact harshly on the finances of individuals and their families, and the economies of nations. People with diabetes who depend on life-saving insulin pay the ultimate price when access to affordable insulin is lacking."

\section{B. Obesity}

Obesity can be defined as an excessive amount of fat that increases the risk of medical illness and premature death (Fock \& Khoo, 2013). According to WHO, obesity has nearly tripled since 1975 (WHO, 2020). In 2016, more than 1.9 billion adults aged 18 years and older were overweight, with $13 \%$ being obese (WHO, 2020). In addition, in 2019, at least 40 million children under the age of 5 were overweight or obese (WHO, 2020). According to WHO, the main drivers of obesity include poor and misaligned diet, insufficient physical activity, sedentary lifestyle, changing mode of transportation, increasing urbanization (WHO, 2020). The United States is no exception.

In the United States, it is forecast "a $33 \%$ increase in obesity prevalence and a $130 \%$ increase in severe obesity prevalence over the next 2 decades (Finkelstein et al., 2012). Also, in the United States (and globally) obesity has been found to be a major risk factor for diabetes (CDC, 2019; Alonso, Decora, \& Bauer, 2019; Bhupathiraju \& Hu, 2016; Chobot et al., 2018; OECD, 2019), especially among "African Americans compared with all other race and Hispanic origin groups" (Hales et al. 2020). The close relationship between obesity and diabetes has led to the connotation 'diabesity,' meaning that the majority of individuals with diabetes are overweight or obese (Leitner et al. 2017). Tajik et al. (2019) "being classified as overweight and obese increased the risk of T2DM in comparison with normal weight. Metabolically unhealthy (MUH) individuals are at higher risk of T2DM in all categories of body mass index (BMI) compared with metabolically healthy individuals." In concordance, Janghorbani et al. (2017) "obesity is a risk factor for T2D with individuals who are metabolically healthy obese (MHO), metabolically unhealthy overweight (MUOW), and metabolically unhealthy obese (MUO) in excess risk of T2D." The economic costs due to obesity can be burdensome (Loureiro \& Nayga, 2005).

In the United States, for example, in 1990 the total economic cost of diabetes associated disease was put at estimated $\$ 68.8$ billion, with direct cost of $\$ 45.8$ billion and indirect cost of $\$ 23$ billion (Wolf \& Colditz, 1994). Five years later in 1995 , the total cost attributable to obesity amounted to $\$ 99.2$ billion $(5.7 \%$ of U.S. national health expenditure), out of which nearly $\$ 52$ billion were direct medical costs, and approximately $\$ 4$ billion in lost productivity, reflecting 39.2 million days of lost work (Wolf \& Colditz, 2012). Currently in the United States, medical costs attributed to obesity were estimated $\$ 149.4$ billion (Kim \& Basu, 2016). In contrast, if obesity in the United States were to remain at 2010 levels, the combined savings in medical expenditures over the next 2 decades would be $\$ 549.5$ billion (Finkelstein et al., 2012). Comparatively, the economic cost of obesity in the United States is similar to what is obtainable in "other industrialized countries which indicate that the cost of obesity is between $2 \%$ to $5 \%$ of the total cost of health care in industrialized nations" (Levy, Levy, \& Basdevant, 1995). A recent report by the Organization for Economic Cooperation and Development (OECD), a body of industrialized economies, found that OECD spend estimated $\$ 311$ billion annually to treat obesity induced diseases (OECD, 2019, p. 75). Overall, obesity will cost the 52 OECD countries $\$ 425$ billion per year, equating to average of $3.3 \%$ lower GDP, and $8 \%$ of total health spending (OECD, 2019, p. 75). Obesity is linked to environmental risk factor.

\section{Environmental Risk}

The influence of neighborhood and environmental factors on health is increasingly being recognized and studied in the recent years (Dendup et al, 2018; Diez Roux \& Mair, 2010; Black \& Macinko, 2008; Marshall, Brauer, \& Frank, 2009; Hankey \& Marshall, 2017; WHO, 2018). According to WHO, 24\% of all global deaths are linked to environmental risk factors, roughly 13.7 million deaths annually (WHO, 2016). Also, more than one quarter of the 6.6 million under-five child deaths every year are associated with environment-related causes and conditions (WHO, 2016, p. 13). In addition, exposure to ambient air pollution is thought to increase the risk of premature birth, low birth weight and infant mortality (WHO, 2016, p. 44). And diabetes is no exception. 
A recent Global Burden of Disease study covering 194 countries and territories found that $\mathrm{PM}_{2.5^{3}}$ air pollution is associated with "increased risk of diabetes...with the burden skewed more heavily towards lowincome and lower-to-middle-income countries" (Bowe et al., 2018, p. e301). The study estimate the attributable burden of disease (ABD) and disability-adjusted life-years (DALYs) of diabetes cases linked to environmental air pollution are highest in the ten most populous countries in the world (Table 6), China with the highest ABD of 600,000, followed by India with an ABD of 591,000, and the USA third, with an ABD of 150,000 (p. e305). Prior, the U.S. Environmental Protection Agency (EPA), found "people living with diabetes are considered at high risk for adverse health effects from exposure to harmful particles, or air pollution found both indoors and outdoors" (EPA, 2007). The poor air quality situation is worse in the communities and neighborhoods of racial/ethnic minorities in the United States (Ash \& Boyce, 2018).

\section{Table 6: Attributable Burden of Diabetes Associated with Air Pollution Exposure Globally and for the Top Ten Most Populous Countries}

\begin{tabular}{clcc}
\hline Rank & Country & $\begin{array}{c}\text { Attributable } \\
\text { Burden of } \\
\text { Disease }\end{array}$ & $\begin{array}{c}\text { Attributable Burden } \\
\text { of Disease/100,000 } \\
\text { Population }\end{array}$ \\
\hline Global & $3,002,900$ & $40 \cdot 6$ \\
2 & China & 600,300 & $43 \cdot 9$ \\
3 & India & 590,500 & $44 \cdot 9$ \\
4 & USA & 149,500 & $46 \cdot 3$ \\
5 & Pakistan & 112,400 & $58 \cdot 8$ \\
6 & Bangladesh & 104,800 & $40 \cdot 7$ \\
7 & Brazil & 69,800 & $43 \cdot 1$ \\
8 & Russia & 39,800 & $23 \cdot 8$ \\
9 & Japan & 36,170 & $24 \cdot 8$ \\
10 & Nigeria & 24,900 & $27 \cdot 7$ \\
\hline
\end{tabular}

Source: Benjamin Bowe et al. (2018). "The 2016 Global and

National Burden of Diabetes Mellitus Attributable to PM 2.5

Air Pollution." Lancet Planet Health, p. e306.

https://www.thelancet.com/action/showPdf?pii=S2542-5196\%2818\%2930140-2.

In the "United States," argued Lambert (2019) "pollution, much like wealth, is not distributed equally," or, as Brown et al. (2013) put it, "collective illness experience in the United States" is not the same for African Americans and Whites. Bullard (1993, p. 15) "Communities are not created equal. In the United States, for example, some communities are routinely poisoned while the government looks the other way. Environmental regulations have not uniformly benefitted all segments of society. People of color (African Americans, Latinos, Asians, Pacific Islanders, and Native Americans) are disproportionately harmed by industrial toxins on their jobs and in their neighborhoods." The foregoing quotes go a long way to support the "charge that poor and minority communities are dumping grounds for environmental hazards" (Northridge \& Shepard, 1997, p. 730). Concurring, Downey and Hawkins (2008, p. 759), "racial minorities are disproportionately burdened by environmental hazards." Some scholars and analysts have called this phenomena "pollution inequity" (Tessum et al., 2019, p. 6001), "environmental racism" (Northridge \& Shepard, 1997; Newkirk, 2018; Grossman, 1993, p. 326; Bullard, 1993), "ecology of toxic inequality" (Sampson \& Winter, 2016, p. 3), and "environmental injustice" (Brulle \& Pellow, 2006), thereby reinforcing the health disparity gap between minorities and Whites. Many studies have explored this disparity (Gwynn \& Thurston, 2001; Olden \& White, 2005; Downey \& Hawkins, 2011). More recently, according to the American Lung Association (2020a, p.44), "The burden of air pollution is not evenly shared. Poorer people and some racial and ethnic groups are among those who often face higher exposure to pollutants and who may experience greater responses to such pollution" and vulnerability to health problems.

The most recent EPA review of the research on the health effects of particle pollution (American Lung Association, 2020b) concluded that "there is strong evidence demonstrating that black and Hispanic populations, in particular, have higher risk exposures than non-Hispanic white populations"' (U.S. EPA, 2019, section 12.5.4) and that "there is consistent evidence across multiple studies demonstrating an increase in risk for nonwhite populations" (U.S. EPA, 2019, pp. 12-38). [See also Federal Register, vol. 85, no. 84, April 30, 2020, p. 24114]. Also, due to decades of residential segregation and redlining, African Americans tend to live where there is greater exposure to air pollution (Nardone, et al., 2020) and by implication are more susceptible to health risks

\footnotetext{
3 " $\mathrm{PM}_{2.5}$ is the most widely studied air pollutant - is associated with increased risk of cardiovascular disease, pulmonary disease, kidney disease, and other non-communicable diseases and contributed to about $4 \cdot 2$ million premature deaths in 2015" (Bowie, et al., 2018).
} 
including diabetes. A 2019 study by the American based Union of Concerned Scientists, a nonprofit science advocacy, found "inequitable exposure to air pollution from vehicles in American Northeast and Mid-Atlantic regions, with communities of color breathing 66 percent more air pollution than White residents." Another 2016 study found that long-term exposure to airborne pollution is associated with racial segregation, with more highly segregated areas suffering higher levels of exposure (Bravo et al., 2016). As also, racial segregation is suspected in the prevalence of lead poisoning in the African American neighborhoods and has contributed to the legacy of Black disadvantage in the United States (Sampson \& Winter, 2016).

In Louisiana, for example, the region between Baton Rouge and New Orleans has been infamously called the "Cancer Alley" (Pezzullo, 2003; Berry 2003; Taylor 2014) because this area, particularly "predominantly Black and poor communities" (Baurick, Younes, \& Meiners, 2019) "host a disproportionate number of hazardous and noxious facilities" (Taylor, 2014, p. 2) including "about 135 petrochemical plants" (Taylor, 2014, p. 20), that tend to release "air toxins and pollutants known or suspected to cause cancer or other serious health problems" (Louisiana Department of Environmental Quality, Air Toxics Monitoring, n.d.). In fact, it has been found that "numerous cancer cases occur in the Cancer Alley"5 (Taylor, 2014, p. 20), as people living in the Cancer Alley are "more than 50 times as likely to get cancer than the average American" (Pasley, 2020), and "while air quality has improved for decades across the U.S., but Louisiana is backsliding...a crush of new industrial plants will increase concentrations of cancer-causing chemicals in predominantly black and poor communities" (Baurick, Younes, \& Meiners, 2019). The federal cancer picture mimic Louisiana's.

A CDC and National Cancer Institute study of cancer death rates from 2013 to 2017 indicates that African Americans are more likely to die from cancer than any other racial group in the United States (CDC \& National Cancer Institute, 2020). In the 2013-2017 study period, the death rate from all cancers was 181.7 per 100,000 for African Americans (compared to 158.3 per 100,000 nationally), 159.0 per 100,000 for Whites, 98.9 per 100,000 for Asian and Pacific Islanders, 106.2 per 100,000 for Native Americans, and 112.3 per 100,000 for Hispanic (CDC \& National Cancer Institute, 2020). Cancer is the second leading cause of death in the United States, after heart disease. One of every four deaths in the United States is due to cancer (CDC \& National Cancer Institute, 2020). In 2017 (latest incidence data available), in the United States, 1,701,315 new cases of cancer were reported, and 599,099 people died of cancer. For every 100,000 people, 438 new cancer cases were reported and 153 people died of cancer (CDC \& National Cancer Institute, 2020). Accordingly, the long association of environmental inequity with minority communities in the United States continue to reinforce health disparity, not the least diabetes occurrence and impact. Environmental inequity is linked to racial discrimination with implications for diabetes risk factors.

\section{Discrimination}

Nwagbara (2020) found that racial discrimination is partly to blame for African Americans health disparity problem in the United States. Another recent report found that close to " $25 \%$ of African Americans avoid medical care even when in need, for fear of discrimination" (Harvard T.H. Chan School of Public Health, Robert Wood Johnson Foundation, and National Public Radio, 2017, p. 1). The literature further reveal that due to racial discrimination African Americans tend to receive low quality of care for basic hospital services (Ayanian, 1999; Noonan, Velasco-Mondragon, \& Wagner, 2016; Scott \& Wilson, 2011; Gerend \& Pai, 2008; Hostetter \& Klein, 2018). Pinderhughes (1996, p. 231) "most common victims of environmental hazards and pollution are minorities and the poor. Disproportionate exposure to environmental hazards is part of the complex cycle of discrimination and deprivation faced by minorities in the United States" including health inequity. The impact of discrimination/racism on diabetes outcomes is no exception.

Robert Anderson (1998, p. 689) observed "in the United States racism and diabetes are in the heart of darkness." Tull and Chambers (2001) echoed similar sentiments, "internalized racism is associated with glucose intolerance among Black Americans...may also contribute to the unexplained excess of type 2 diabetes in that group." Wagner et al. (2011, p. 224) found that "African American women believed that racism affects their diabetes self-management and control...with exposure to novel racial stressors." Bacon et al. (2017) "Black Women's Health Study" of 59,000 African American women spanning 16 years period found "exposure to 'every day racism' (interpersonal racism in daily life) and 'lifetime racism' (treated unfairly due to race with respect to police, housing or work) increased risk of type 2 diabetes."

Moody-Ayers et al. (2005) study of "perceived societal racism in African Americans aged 50 and older with

\footnotetext{
${ }^{4}$ Cancer Alley parishes (counties) includes: Ascension, Assumption, East Baton Rouge, Iberville, Jefferson, Orleans, Plaquemines, St. Charles, St. James, St. John the Baptist, West Baton Rouge (Taylor, 2014, p. 20).

${ }^{5}$ According to the CDC, in 2017 (latest data), Louisiana had the fifth-highest cancer death rate in the country, for every 100,000 people in Louisiana, 175 died of cancer, behind Kentucky (186), Mississippi (183), West Virginia (179), Oklahoma (177).

Source: CDC and National Cancer Institute (June 2020). "Cancer Burden: All Types of Cancer, 2017." United States Cancer Statistics: Data Visualizations.

https://gis.cdc.gov/Cancer/USCS/DataViz.html.
} 
type 2 diabetes mellitus" found that "patients' day-to-day experiences of societal racism can influence the patient trust in the medical system and their adherence to medical advice or engagement in self-management of their chronic conditions." Auslander et al. (1997) investigation concluded, "mothers of children with diabetes who reported greater perceptions of racism were significantly less satisfied with their children's medical care than those from less stressful environments." Nowhere is the health complications ${ }^{6}$ of diabetes more pronounced than in the disparity in limb amputation risks between ethnic minorities and Whites. To put it vividly, Presser (2020) " they [African Americans] are disproportionately diabetic...put at risk by an array of factors, from unequal health care access to racist biases to cuts in public health funding. These elements have long driven disparities, particularly across the South. One of the clearest ways to see them is by tracking who suffers diabetic amputations, which are, by one measure, the most preventable surgery in the country" [America].

\section{Diabetic Amputations: The African American Experience}

According to WHO, the global cases of diabetes rose more than 290\% in 2014 from 1980, representing 422 million patients (WHO, 2020). This has led to increasing number of individuals with diabetic foot disease, up to $75 \%$ of lower extremity amputations (LEAs) being performed in these patients (Narres, 2017, p. 2). The United States is no exception.

Back in 2001 Wrobel, Mayfield, and Reiber found that in the United States "patients with diabetes were 10 times more likely to undergo major amputation" (p. 861). Nearly twenty years later in 2018, a major report in the Diabetes Care, the official journal of the American Diabetes Association reached a similar conclusion, indicated that diabetic related "lower-limb amputations may be rising in the United States after decades of decline" (Caffrey, 2018). According to the study which covered the years between 2009 and 2015, the rate of amputations in the United States grew 50\% during the period under review (Geiss, et al., 2018). In the United States, diabetics undergo about 120,000 amputations each year (Geiss, 2018, p. 53), often in low-income and underinsured neighborhoods (Presser, 2020). The problem is worse in the African American population.

Table 7 shows the outcomes of patients admitted to the hospital from 2003-2015 ${ }^{7}$ for diabetic foot infections (DFIs) across various racial/ethnic groups including Whites, African Americans, Hispanics, and Native Americans (Tan, et al., 2019). Applying multivariable logistic models, the researchers studied the association between racial and ethnic groups and outcomes, including major (lower extremity amputation above the ankle) and minor (amputation below the ankle) amputations, endovascular intervention, and open surgery (Tan, et al., 2019). Major amputations were highest for African Americans (7.6\%), followed by Native Americans (7.1\%) and Hispanics (6.9\%), than it is for Whites (5.4\%). Similarly, the number of minor amputations were highest for African Americans (31.6\%), followed by Hispanics (31.5\%), than Whites (29.3\%), and Native Americans (27.8\%).

Table 7: Outcomes of Patients with Diabetic Foot Infections, 2003-2015

\begin{tabular}{|c|c|c|c|c|c|c|}
\hline Characteristic & $\begin{array}{l}\text { Overall } N= \\
150,701\end{array}$ & $\begin{array}{l}\text { White } \mathrm{N}= \\
98,361\end{array}$ & $\begin{array}{l}\text { African American } \\
\mathrm{N}=24,583\end{array}$ & $\begin{array}{l}\text { Hispanic N } \\
=24,472\end{array}$ & $\begin{array}{l}\text { Native } \\
\text { American } \mathrm{N}= \\
1,631\end{array}$ & $\begin{array}{l}\text { Other N } \\
=1,654\end{array}$ \\
\hline Mortality, n (\%) & $1,047(0.7)$ & $690(0.7)$ & $178(0.7)$ & $158(0.6)$ & $8(0.5)$ & $13(0.8)$ \\
\hline $\begin{array}{l}\text { Minor amputation, } \\
\mathrm{n}(\%)\end{array}$ & $45,278(30)$ & $\begin{array}{l}28,806 \\
(29.3)\end{array}$ & $7,774(31.6)$ & $7,719(31.5)$ & $453(27.8)$ & $\begin{array}{l}526 \\
(31.8)\end{array}$ \\
\hline $\begin{array}{l}\text { Major amputation, } \\
\mathrm{n}(\%)\end{array}$ & $9.039(6)$ & $5,268(5.4)$ & $1,861(7.6)$ & $1,678(6.9)$ & $116(7.1)$ & $116(7)$ \\
\hline Open bypass, $n(\%)$ & $3,151(2.1)$ & $1,992(2)$ & $524(2.1)$ & $575(2.3)$ & $14(0.9)$ & $46(2.8)$ \\
\hline $\begin{array}{l}\text { Endovascular } \\
\text { intervention, } \mathrm{n}(\%)\end{array}$ & $8,689(5.8)$ & $5,407(5.5)$ & $1,443(5.9)$ & $1,650(6.7)$ & $81(5)$ & $108(6.5)$ \\
\hline
\end{tabular}

Source: Adapted from Tze-Woei Tan et al (2019). "Disparities in Outcomes of Patients Admitted with Diabetic Foot Infections." PLoS ONE 14(2), e0211481.

https://www.ncbi.nlm.nih.gov/pmc/articles/PMC6361439/pdf/pone.0211481.pdf.

${ }^{6}$ Diabetic foot ulcers (DFU) and diabetic foot infections (DFI) are the leading causes of amputations (Lefebvre \& Lavery, 2011). African Americans (AAs), Hispanics, and Native Americans (NAs) have a higher prevalence of diabetes than Whites (Spanakis \& Golden, 2013; CDC, n.d.; Cheng, et al., 2019). Consequently, the incidence of DFUs and amputations are disproportionately higher in AAs, Hispanics, and NAs (Lavery et al. 1996; Margolis, et al., 2011, Data Points \#1 and \#2; Tan, et al., 2019).

${ }^{7}$ The study utilized National Inpatient Sample (NIS). The NIS is part of the Healthcare Cost and Utilization Project (HCUP), is the largest publicly available all-payer health care database and collects data for more than 7 million hospital stays every year (Tan, et al., 2019). 
Other studies have also reached similar conclusions. According to a recent Dartmouth study, Black patients' amputation rate is nearly three times higher than the rate among others (Goodney, et al., 2014, p. 12). "Racial and ethnic minorities" wrote Fakorede (2018) not only "have a higher prevalence and greater burden of diabetes compared with Whites," but also, "African Americans are 4 times more likely to experience diabetes-related amputation than Whites." "Blacks and Hispanics with...diabetes experience a greater incidence and odds of amputation when compared with Whites" (Lefebvre \& Lavery, 2011; Margolis, et al, 2011; Goldberg, et al. 2012; Fakorede, et al., 2019; Girijala \& Bush, 2018). Earlier, Feinglass et al. (2008) census data analysis of racial disparities in lower extremity amputation rates in Northern Illinois, 1987-2004 (18 years) found that "despite progress in reducing the overall major amputation rate in northern Illinois, racial disparities have remained remarkably constant." The "predominantly African American area of the South and West sides of Chicago, with less than $15 \%$ of the area population, accounted for $27 \%$ of all amputation discharges."

Rucker-Whitaker, Feinglass, and Pearce (2003) analysis of "population-based hospital data indicate that African American patients undergo major lower extremity (LE) amputation 2 to 3 times more frequently than white patients." The disparity is because "African American patients undergo repeat major amputation at a significantly higher rate than Whites." Goldberg et al. (2012) exploration of Medicare diabetic patients 23,976 amputations between 1999 and 2006, found that "high-risk patients represent a minority of Medicare diabetic patients but account for $50 \%$ of all amputations, and this effect is magnified in African Americans." Lavery et al. (1997) found "African Americans diabetes higher prevalence or severity of risk factors may explain the excess mortality observed in African-Americans following lower extremity amputations." In all, Presser (2020) has called it "The Black American Amputation Epidemic."

\section{Mississippi Delta - "Black American Amputation Epidemic" Epicenter}

Geographic variation cluster analysis in the rate of diabetic prevalence, amputation, and mortality is in order. The Mississippi Delta region ${ }^{8}$ is a case in point. The region has the highest concentration of diabetic amputations, prevalence, and mortality in the United States (Figures 1, 2, and 3). Mississippi has been called the "amputation capital of the United States" and it is considered the epicenter of the diabetic "Black American Amputation Epidemic" (Presser, 2020). Also, Mississippi has a large African American population, ${ }^{9}$ it has one of the highest rates of diabetes (rank number 3, Table 8), and the highest poverty rate at $19.1 \%$ (same as Louisiana) in the United States. ${ }^{10}$ Consequently, Mississippi ${ }^{11}$ can be generalized as representative of the diabetes induced "Black American Amputation Epidemic" with its "dire implications for disability and mortality" (Wrobel, Mayfield, \& Reiber, 2001, p. 862). The "Black American Amputation Epidemic" toll is so heavy in the Mississippi Delta that one Dr. Foluso Fakorede, "a crusading cardiologist" and the "only cardiologist in Bolivar County, Mississippi" (Presser, 2020) has envisioned building a lab called "Amputation Prevention Institute" (Presser, 2020) in the Delta.

\footnotetext{
${ }^{8}$ The Mississippi Delta region runs across eight states: Alabama, Arkansas, Illinois, Kentucky, Louisiana, Mississippi, Missouri, and Tennessee. Source: Delta Regional Authority (2015, February). "Today's Delta - A Research Tool for the Region." Second Edition.

https://dra.gov/images/uploads/content_files/Todays_Delta_FINAL_print-w-borders.pdf.

${ }^{9}$ African American population is $1,103,101$ or $37 \%$ of the total 2,967,297 Mississippi population estimate in 2018. Mississippi's 37\% African American population is nearly double the average of 22\% African American population in the South. Source: U.S. Census Bureau. American Fact Finder.https://www2.census.gov/programssurveys/popest/tables/2010-2018/state/asrh/PEPSR6H.pdf

${ }^{10}$ Jessica Semega et al. (2020, September 15). "Income and Poverty in the United States: 2019." U.S. Census Bureau. https://www.census.gov/library/publications/2020/demo/p60-270.html.

11 In 2016, Mississippi ranked first in the nation for overall diabetes prevalence, with an estimated 308,295 adult Mississippians living with diabetes (over $13.6 \%$ of the adult population). Mississippi Department of Health. https://msdh.ms.gov/msdhsite/_static/43,0,296.html.
} 
Figure 1: Average Annual Amputations, 2007-9

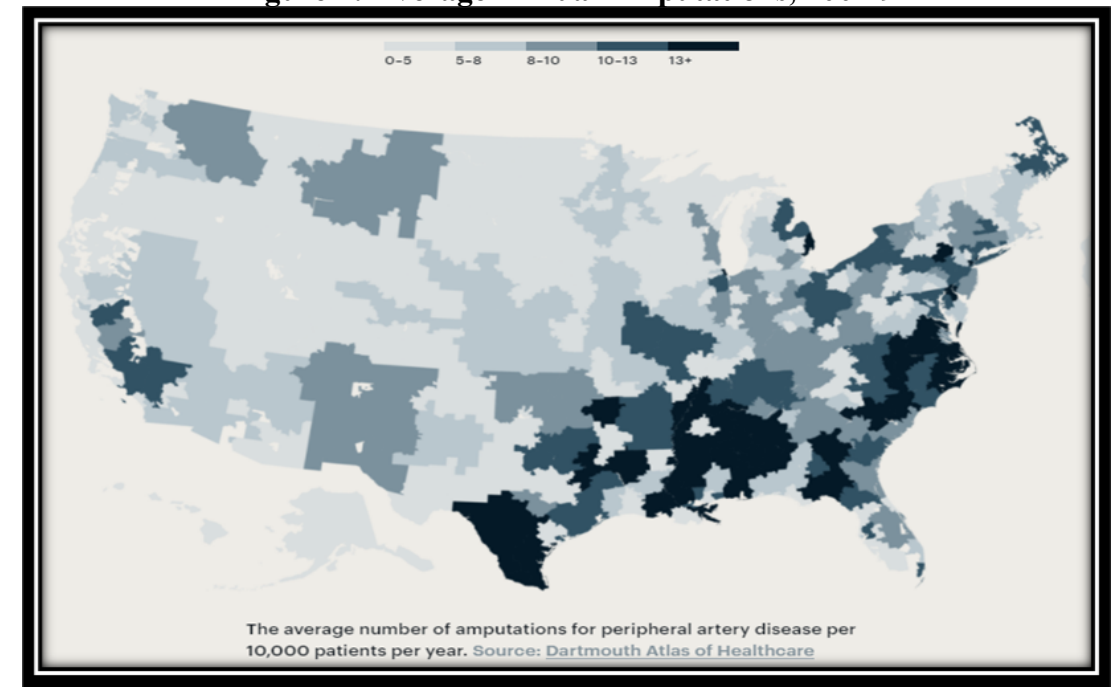

Adapted from Lizzie Presser (May 19, 2020). "The Black American Amputation Epidemic." PROPUBLICA.

https://features.propublica.org/diabetes-amputations/black-american-amputation-epidemic/.

Lower extremity amputation (LEA) in patients with diabetes results in high mortality, reduced quality of life, and increased medical costs (Narres, et al., 2017, p. 1). Diabetic persons have a 15 times higher risk of LEA than nondiabetic individuals (Most \& Sinnock, 1983; Bild et al., 1989) and elevated risk of foot ulcer as a result (Paisey, et al. 2018). African Americans and other historically underserved populations are less likely to get lower extremity amputation alternative attention such as, "prior arterial intervention and peripheral vascular intervention (PVI) than Whites" (Fakorede, et al. 2019). In the same breath, African Americans are more likely to undergo primary amputation than revascularization to improve arterial blood flow than Whites (Tan, et al., 2019). Furthermore, it is widely believed that African-American patients experience worst quality of life after PVI, than their White counterparts (Fakorede, et al., 2019; Zaitoun, et al., 2017), leading to more health comorbidities. Also, it has been shown that "African American are less likely to be evaluated with an angiogram than are White patients" (Henry, et al., 2011), leading to the "conclusion that physicians should not be dissuaded from treating African-American patients with PVI when appropriate" (Fakorede, et al., 2019).

Figure 2: County-level Prevalence of Diagnosed Diabetes among Adults Aged 20 Years or Older, United States, 2004, 2008, and 2016

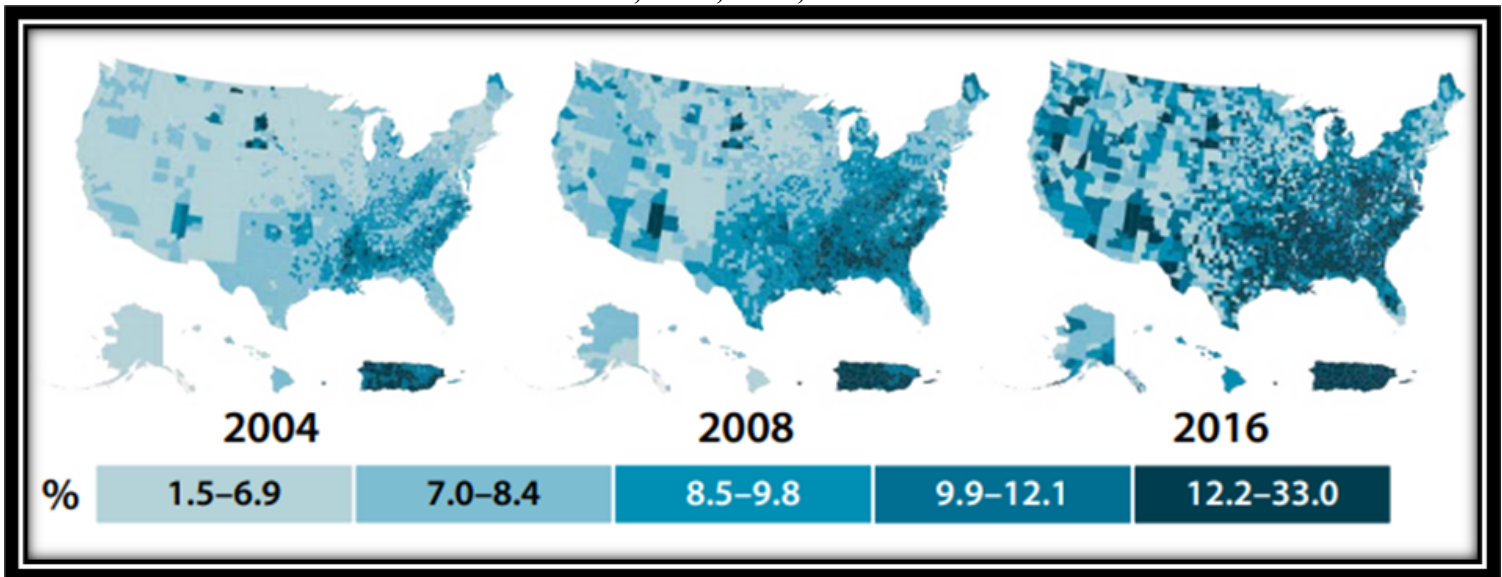

Adapted from CDC, National Diabetes Statistics Report 2020, p. 5 
Figure 3: United States - Diabetes Mortality by State

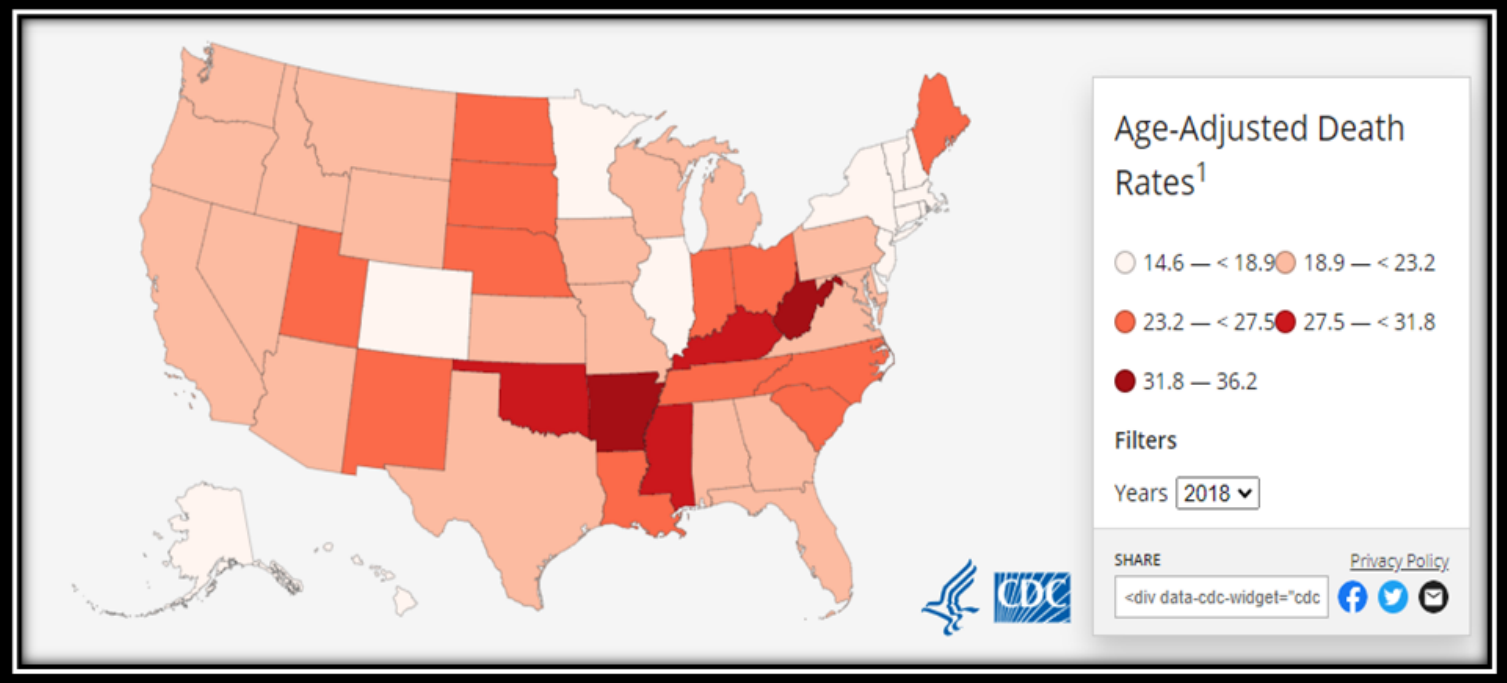

${ }^{1}$ The number of deaths per 100,000 population

Source: U.S. Centers for Disease Control and Prevention (CDC), "Diabetes Mortality by State." https://www.cdc.gov/nchs/pressroom/sosmap/diabetes mortality/diabetes.htm.

Table 8: United States - Diabetes Death Rate* by State 2018

\begin{tabular}{|c|c|c|c|c|c|}
\hline Rank & State & Rate & Rank & State & Rate \\
\hline 1 & West Virginia & 36.2 & 25 & Wyoming & 21.4 \\
\hline 2 & Arkansas & 32.3 & 27 & Texas & 21.1 \\
\hline 3 & Mississippi & 30.6 & 28 & Missouri & 20.8 \\
\hline 4 & Oklahoma & 29.0 & 29 & Washington & 20.4 \\
\hline 5 & Kentucky & 27.9 & 30 & Illinois & 20.3 \\
\hline 6 & Louisiana & 26.9 & 31 & Pennsylvania & 20.2 \\
\hline 7 & New Mexico & 26.1 & 31 & Wisconsin & 20.2 \\
\hline 8 & Iowa & 26.0 & 33 & Florida & 19.8 \\
\hline 8 & Nebraska & 26.0 & 34 & Maryland & 19.6 \\
\hline 10 & Ohio & 25.4 & 35 & Alabama & 19.4 \\
\hline 11 & South Carolina & 24.8 & 36 & Nevada & 19.2 \\
\hline 12 & Tennessee & 24.5 & 37 & Montana & 19.1 \\
\hline 13 & North Dakota & 24.1 & 38 & Delaware & 18.8 \\
\hline 14 & North Carolina & 23.9 & 38 & Minnesota & 18.8 \\
\hline 15 & Utah & 23.5 & 40 & Indiana & 18.6 \\
\hline 16 & Maine & 23.4 & 41 & New York & 18.2 \\
\hline 17 & South Dakota & 23.3 & 41 & Vermont & 18.2 \\
\hline 18 & Oregon & 22.9 & 43 & Alaska & 17.7 \\
\hline 19 & Virginia & 22.9 & 44 & New Hampshire & 17.3 \\
\hline 20 & Kansas & 22.6 & 45 & Rhode Island & 17.2 \\
\hline 21 & Arizona & 22.4 & 46 & New Jersey & 16.6 \\
\hline 22 & Georgia & 22.1 & 47 & Colorado & 16.1 \\
\hline 23 & Idaho & 21.9 & 47 & Hawaii & 16.1 \\
\hline 23 & Michigan & 21.9 & 49 & Massachusetts & 15.8 \\
\hline 25 & California & 21.4 & 50 & Connecticut & 14.6 \\
\hline
\end{tabular}

\section{Conclusion and Policy Recommendations}

This paper examined the diabetes "epidemic" in the United States and its devastating impact on African 
Americans health, compared to Whites. The paper find that diabetes not only has disproportionate impact on the health of African Americans, especially lower limb amputations, but also, it has widened the gap in health disparity between African Americans and Whites. As Girijala and Bush (2018) put it, "the current body of literature and data analyses show a clear association between race, coexisting diseases, and the risk of a negative limb outcome." In addition, there is a strong correlation between African American high diabetes prevalence and risk factors of poverty, obesity, environment, and discrimination. The findings are consistent with the body of research in the empirical literature as has been quoted profusely in the paper. Furthermore, the findings will be important to health care policymakers, administrators, providers, educators, analysts, and students as well as advocates for underserved populations towards policy solutions for health disparity.

Diabetes should be treated as a major public health problem for African Americans and other peoples of color. To address race disparities in diabetes prevalence and care, policymakers should address diabetes enabling factors including poverty, obesity, nutrition imbalance, environmental toxins, racial discrimination, and poor housing. The following measures could be taken to control and the reverse the trend of diabetes exposure in the African American population:

- Better understanding of the complex roles that economic inequality, discrimination, environment, housing segregation, obesity play in the disproportionate burden of diabetes in the African American population

- Know that diabetes is a public health crisis just as "Racism is a public health crisis" (Michelle Williams, T.H. Chan School of Public Health, Harvard University). https://www.hsph.harvard.edu/news/racism-is-apublic-health-crisis/.

- Government policies, laws, and hospital practices should encourage equitable care for at risk-patients and aim to end racial disparity in amputations. ${ }^{12}$

- Allocate more funding for education, research, prevention, and better management of diabetes.

- Black physician leadership will be necessary if African American health disparity is to be resolved (Byrd \& Clayton, 1992, p. 189; deShazo, Smith, \& Skipworth, 2014, Part 1and 2; deShazo and Parker, 2018), and diabetes is no exception. As Dr. David Satcher, African American, former Surgeon General of the United and the director of the Centers for Disease Control and Prevention, astutely suggested: "this...leaders must be prepared to effect critical public policy decisions, including improvements in access to quality care, and health promotion and disease prevention, with the goal of eliminating disparities in health and achieving health equity" (Satcher, 2020, p. 11).

- Continue to monitor and reduce disparities - the Agency for Healthcare Research and Quality (AHRQ) publishes an annual national report highlighting disparities in health care quality by race/ethnicity, age, and sex; the Office of Minority Health is tasked with developing policies and programs to eliminate disparities among racial and ethnic minority groups; the Health Resources and Services Administration (HRSA) is tasked with providing grants to states, local governments, and community-based organizations for care and treatments for low-income, uninsured, or other vulnerable populations; the Indian Health Service serves American Indians and Alaska Natives who belong to more than 500 federally recognized tribes in 37 states, and the service is fully funded through the federal government (Tikkanen, et al., 2020).

- Boost primary care - according to experts, "primary care is the means by which the two main goals of a health services system, optimization and equity of health status, are approached." Primary care provides the entry into the system for all new needs and problems, provides person-focused (not disease-oriented) care, and coordinates or integrates care, regardless of location and provider (Johns Hopkins University, "Definitions," Bloomberg School of Public Health, n.d.). https://www.jhsph.edu/research/centers-andinstitutes/johns-hopkins-primary-care-policy-center/definitions.html.

\section{References}

Alonso, L., Decora, L., \& Bauer, U. E. (2019). Obesity and Diabetes in the Winnebago Tribe of Nebraska: From Community Engagement to Action, 2014-2019. Preventing Chronic Disease, 16:190181. DOI: http://dx.doi.org/10.5888/pcd16.190181. CDC, Public Health Practice Brief, vol. 16. https://www.cdc.gov/pcd/issues/2019/19_0181.htm.

American Diabetes Association. (2018). Economic Costs of Diabetes in the U.S. in 2017.

12 In October 2020, for example, Congressman Donald M. Payne Jr., a Democrat from New Jersey, introduced a comprehensive bill to reduce unnecessary amputations and address racial disparities in amputations - "The Amputation Reduction and Compassion Act of 2020.”

Lizzie Presser (October 19, 2020). New Bill Aims to End Racial Disparities in Amputations. ProPublica. https://www.medscape.com/viewarticle/939381. 
https://care.diabetesjournals.org/content/early/2018/03/20/dci18-0007.full-text.pdf.

American Lung Association. (2020a). State of the Air. https://www.stateoftheair.org/assets/SOTA-2020.pdf. (2020b, April 20). Disparities in the Impact of Air Pollution. https://www.lung.org/cleanair/outdoors/who-is-at-risk/disparities.

Anderson, R. (1998). Into the Heart of Darkness: Reflections on Racism and Diabetes Care. The Diabetes Educator, 24(6), 689-692. https://journals.sagepub.com/doi/pdf/10.1177/014572179802400604.

Ash, M., \& Boyce, J. K. (2018, October 16). Proceedings of the National Academy of Sciences of the United $\begin{array}{lllll}\text { States of } & \text { America } & \text { (PNAS), } & 115(42), & 10636-10641 .\end{array}$ https://www.pnas.org/content/pnas/115/42/10636.full.pdf.

Auslander, W. F. (1997). Mothers' Satisfaction with Medical Care: Perceptions of Racism, Family Stress, and Medical Outcomes in Children with Diabetes. Health \& Social Work, 22(3), 190-199. https://academic.oup.com/hsw/article-abstract/22/3/190/593633.

Ayanian, J.Z., Weissman, J.S., Chasan-Taber, S., \& Epstein, A.M. (1999). Quality of Care by Race and Gender for Congestive Heart Failure and Pneumonia. Medical Care, 37(12), 1260-1269. https://www.ncbi.nlm.nih.gov/pubmed/10599607.

Baurick, T., Younes, L., \& Meiners, J. (2019, October 30). Polluter's Paradise - Welcome to "Cancer Alley," Where Toxic Air Is About to Get Worse. PROPUBLICA. https://www.propublica.org/article/welcome-tocancer-alley-where-toxic-air-is-about-to-get-worse.

Berry, G. R. (2003). Organizing Against Multinational Corporate Power In Cancer Alley: The Activist Community as Primary Stakeholder. Organization \& Environment, 16(1), 3-33. https://journals.sagepub.com/doi/abs/10.1177/1086026602250213.

Bhupathiraju, S. N., \& Hu, F. B. (2016). Epidemiology of Obesity and Diabetes and Their Cardiovascular Complications. Circulation $\quad$ Research $118(11), \quad 1723-1735$. https://www.ncbi.nlm.nih.gov/pmc/articles/PMC4887150/.

Bild, D. E. et al. (1989, January). Lower-Extremity Amputation in People With Diabetes: Epidemiology and Prevention. Diabetes Care, 12(1), https://care.diabetesjournals.org/content/12/1/24.

Black, J. L., \& Macinko, J. (2008). Neighborhoods and Obesity. Nutrition Reviews, 66(1), 2-20. https://doi.org/10.1111/j.1753-4887.2007.00001.x. https://nyuscholars.nyu.edu/en/publications/neighborhoods-and-obesity.

Bowie, B. et al. (2018). The 2016 Global and National Burden of Diabetes Mellitus Attributable to PM $_{2 \cdot 5}$ Air Pollution. Lancet Planet Health, 2: e301-12. https://www.thelancet.com/action/showPdf?pii=S2542$5196 \% 2818 \% 2930140-2$.

Bravo, M. A. et al. (2016, August). Racial isolation and exposure to airborne particulate matter and ozone in understudied US populations: Environmental justice applications of downscaled numerical model output. Environment International, 92-93,

247-255. https://www.sciencedirect.com/science/article/pii/S0160412016301386\#!

Brown, P. et al. (2013). The Politics of Asthma: Environmental Justice and Collective Illness Experience in the United States. In The Sociology of Health \& Illness. Peter Conrad and Valerie Leiter. $9^{\text {th }}$ edition. pp. 81-93.

Brulle, R. J., \& Pellow, D. N. (2006). Environmental Injustice: Human Health and Environmental Inequalities. Annual Review of Public Health, 27, 103-124. https://www.annualreviews.org/doi/pdf/10.1146/annurev.publhealth.27.021405.102124.

Bullard, R. D. (1993). Confronting Environmental Racism: Voices from the Grassroots. Boston, MA: South End Press.

Bullard, R. D. (1993). Anatomy of Environmental Racism and the Environmental Justice Movement. In Confronting Environmental Racism: Voices from the Grassroots. Boston, MA: South End Press.

Butler, A. M. (2017, August 17). Social Determinants of Health and Racial/Ethnic Disparities in Type 2 Diabetes in Youth. Current Diabetes Report, 17(8): 60. doi: 10.1007/s11892-017-0885-0. https://pubmed.ncbi.nlm.nih.gov/28664253/.

Byrd, W. M., \& Clayton, L.A. (1992, February). An American Health Dilemma: A History of Blacks in the Health System. Journal of the National Medical Association, 84(2), 189-200. https://www.ncbi.nlm.nih.gov/pmc/articles/PMC2637749/.

Caffrey, M. (2018, December 13). Diabetic Amputations May Be Rising in the United States. American Journal of Managed Care. https://www.ajmc.com/view/diabetic-amputations-may-be-rising-in-the-united-states.

Carter, J.S., Pugh, J.A., \& Monterrosa, A. (1996, August 1). Non-insulin-dependent Diabetes Mellitus in Minorities in the United States. Annals of Internal Medicine, 125(3), 221-32. https://pubmed.ncbi.nlm.nih.gov/8686981/.

Centers for Disease Control and Prevention. National Diabetes Statistics Report, 2020. Atlanta, GA: Centers for Disease Control and Prevention, U.S. Department of Health and Human Services; 2020. https://www.cdc.gov/diabetes/pdfs/data/statistics/national-diabetes-statistics-report.pdf 
Centers for Disease Control and Prevention (n.d.). "Overweight and Obesity: Adult Obesity Facts." https://www.cdc.gov/obesity/data/adult.html.

Cheng, Y. J. et al. (2019). Prevalence of Diabetes by Race and Ethnicity in the United States, 2011-2016. Journal of American Medical Association, 322(24), 2389-2398. https://jamanetwork.com/journals/jama/fullarticle/2757817.

Chobot, A. et al. (2018). Obesity and diabetes - Not only a simple link between two epidemics. Diabetes $\begin{array}{lllll}\text { Metabolism Research } & \text { Reviews, 34(7), } 3042 .\end{array}$ https://www.ncbi.nlm.nih.gov/pmc/articles/PMC6220876/.

Connolly, V. et al. (2000). Diabetes Prevalence and Socioeconomic Status: a Population Based Study Showing Increased Prevalence of Type 2 Diabetes Mellitus in Deprived Areas. Journal of Epidemiology \& Community Health, 54(3), 173-177. https://www.ncbi.nlm.nih.gov/pmc/articles/PMC1731634/.

Cowie, C.C. et al. (1993, April 1). Effect of Multiple Risk Factors on Differences between Blacks and Whites in the Prevalence of Non-insulin-dependent Diabetes Mellitus in the United States. American Journal of Epidemiology, 137(7), 719-32. https://pubmed.ncbi.nlm.nih.gov/8484363/.

Cowie, C. C. (1989, October 19). Disparities in Incidence of Diabetic End-Stage Renal Disease According to Race and Type of Diabetes. The New England Journal of Medicine, 321:1074-1079. DOI: 10.1056/NEJM198910193211603. https://www.nejm.org/doi/full/10.1056/nejm198910193211603.

Cunningham, J. et al. (2008, January 13). Socioeconomic Status and Diabetes among Urban Indigenous Australians Aged 15-64 Years in the DRUID Study. Ethnicity \& Health, 13(1), 23-37. https://pubmed.ncbi.nlm.nih.gov/18066736/.

Dendup, T. et al. (2018). Environmental Risk Factors for Developing Type 2 Diabetes Mellitus: A Systematic Review. International Journal of Environmental Research and Public Health, 15(1), 78. https://www.ncbi.nlm.nih.gov/pmc/articles/PMC5800177/.

deShazo, R.D., Smith, R., \& Skipworth, L. B. (2014). Black Physicians and the Struggle for Civil Rights: Lessons from the Mississippi Experience. Part 1: The Forces for and Against Change. The American Journal of Medicine, 127, 920-925. https://www.amjmed.com/article/S0002-9343(14)00483-5/pdf. (2014). Black Physicians and the Struggle for Civil Rights: Lessons from the Mississippi Experience. Part 2: The Forces for and Against Change. The American Journal of Medicine, 127 (11), 1033-1040. https://www.sciencedirect.com/science/article/abs/pii/S0002934314004926.

deShazo, R.D., \& Parker, S.B. (2018). The Underappreciated Doctors of the American Civil Rights Movement: Theodore Roosevelt Mason Howard. In The Racial Divide in American Medicine: Black Physicians and the Struggle for Justice in Health Care. Richard D. deShazo (Ed.). Jackson: University Press of Mississippi.

Diez Roux, A. V., \& Mair, C. (2010). Neighborhoods and Health. Annals of the New Annals of the New York Academy of Sciences, 1186:125-45. doi: 10.1111/j.1749-6632.2009.05333.x. https://pubmed.ncbi.nlm.nih.gov/20201871/.

Downey, L., \& Hawkins, B. (2008). Race, Income, and Environmental Inequality in the United States. Sociological Perspectives, 51(4), 759-781. https://pubmed.ncbi.nlm.nih.gov/19578560/.

Fakorede, F. A. (2018, November 29). Increasing Awareness This National Diabetes Month Can Save Limbs and Lives. American Journal of Managed Care. https://www.ajmc.com/view/increasing-awareness-thisnational-diabetes-month-can-save-limbs-and-lives.

Fakorede, F. A. et al. (2019, January). Mississippi Delta Miracle: Angiographic Screening Yields Dramatic Reduction in Amputations. Cath Lab Digest, 27(1).

https://www.cathlabdigest.com/content/mississippi-delta-miracle-angiographic-screening-yields-dramaticreduction-amputations.

Federal Register, vol. 85, no. 84, Thursday, April 30, 2020, pp. 24094-24144. Environmental Protection Agency (EPA). Review of the National Ambient Air Quality Standards for Particulate Matter. https://www.govinfo.gov/content/pkg/FR-2020-04-30/pdf/2020-08143.pdf.

Feingold, J. et al. (2008). A Census-based Analysis of Racial Disparities in Lower Extremity Amputation Rates in Northern Illinois, 1987-2004. Journal of Vascular Surgery, 47(5), 1001-7. https://pubmed.ncbi.nlm.nih.gov/18358670/.

Finkelstein, E. A. et al. (2012). Obesity and Severe Obesity Forecasts through 2030. American Journal of Preventive Medicine, 42(6), 563-70. doi: 10.1016/j.amepre.2011.10.026. https://pubmed.ncbi.nlm.nih.gov/22608371/.

Fock, K. M., \& Khoo, J. (2013). Diet and Exercise in Management of Obesity and Overweight. Journal of Gastroenterology and Hepatology, 28(S4), 59-63. https://onlinelibrary.wiley.com/doi/full/10.1111/jgh.12407.

Gaskin, D. J. et al. (November 2014). Disparities in Diabetes: The Nexus of Race, Poverty, and Place. American Journal of Public Health, 104(11), 2147-2155. 
Geiss, L. S. et al. (2018, November). Resurgence of Diabetes-Related Non-traumatic Lower Extremity Amputation in the Young and Middle-Aged Adult U.S. Population. Diabetes Care, https://doi.org/10.2337/dc18-1380. https://care.diabetesjournals.org/content/early/2018/11/05/dc18-1380.

Gerend, M. A., \& Pai, M. (2008). Social Determinants of Black-White Disparities in Breast Cancer Mortality: A Review. Cancer Epidemiology Biomarkers \& Prevention, 17(11), 2913-2923. https://cebp.aacrjournals.org/content/17/11/2913.full-text.pdf.

Girijila, R. L., \& Bush, R. L. (2018, October). Review of Socioeconomic Disparities in Lower Extremity Amputations: A Continuing Healthcare Problem in the United States. Cureus, 10(10), e3418. https://www.ncbi.nlm.nih.gov/pmc/articles/PMC6284870/.

Goldberg, J. B. et al. (2012). The Effect of Risk and Race on Lower Extremity Amputations among Medicare Diabetic Patients. Journal of Vascular Surgery, 56(6), 1663-1668. https://www.sciencedirect.com/science/article/pii/S0741521412013146.

Golden, S. H. et al. (2019, August 27). Racial/ethnic differences in the burden of type 2 diabetes over the life course: a focus on the USA and India. Diabetologia, 62(10): 1751-1760. doi: 10.1007/s00125-019-4968-0. https://pubmed.ncbi.nlm.nih.gov/31451876/.

Goodney, P. P. et al. (2014). Variation in the Care of Surgical Conditions: Diabetes and Peripheral Arterial Disease. The Dartmouth Institute for Health Policy and Clinical Practice.

Grossman, K. (1993). Environmental Racism. In The "Racial" Economy of Science. Sandra Harding (ed). Bloomington, IN: Indiana University Press. pp. 326-341.

Gwynn, R. C., \& Thurston, G. D. (2001). The Burden of Air Pollution: Impacts among Racial Minorities. Environmental Health Perspectives, 501-506. https://www.ncbi.nlm.nih.gov/pmc/articles/PMC1240572/pdf/ehp109s-000501.pdf.

Hales, C. M. et al. (2020, February). Prevalence of Obesity and Severe Obesity Among Adults: United States, 2017-2018. U.S. Department of Health and Human Services. Centers for Disease Control and Prevention. National Center for Health Statistics Data Brief, No. 360. https://www.cdc.gov/nchs/data/databriefs/db360h.pdf.

Hankey, S., \& Marshall, J. D. (2017). Urban Form, Air Pollution, and Health. Current Environmental Health Reports, 4(4):491-503. doi: 10.1007/s40572-017-0167-7. https://pubmed.ncbi.nlm.nih.gov/29052114/.

Harris, M.I. (1990). Noninsulin-dependent Diabetes Mellitus in Black and White Americans. Diabetes Metabolism Review, 6(2), 71-90. https://pubmed.ncbi.nlm.nih.gov/2198151/.

Harris, M.I. et al. (1998). Is the Risk of Diabetic Retinopathy Greater in Non-Hispanic Blacks and Mexican Americans than in Non-Hispanic Whites with type 2 Diabetes? A U.S. Population Study. Diabetes Care, 21(8), 1230-5. https://pubmed.ncbi.nlm.nih.gov/9702425/.

Harvard T.H. Chan School of Public Health, Robert Wood Johnson Foundation, and National Public Radio. (2017, October). Discrimination in America: Experiences and Views of African Americans. https://media.npr.org/assets/img/2017/10/23/discriminationpoll-african-americans.pdf.

Hedderson, M. et al. (2012). Racial/Ethnic Disparities in the Prevalence of Gestational Diabetes Mellitus by BMI. Diabetes Care, 35(7), 1492-8. https://pubmed.ncbi.nlm.nih.gov/22619080/.

Henry, A. J. et al. (2011). Socioeconomic and Hospital-Related Predictors of Amputation for Critical Limb Ischemia. Journal of Vascular Surgery, https://www.ncbi.nlm.nih.gov/pmc/articles/PMC3282120/.

Herman, W. H. et al. (2007, October). Differences in A1C by Race and Ethnicity Among Patients With Impaired Glucose Tolerance in the Diabetes Prevention Program. Diabetes Care, 30(10), 2453-2457. https://care.diabetesjournals.org/content/30/10/2453.short.

Hostetter, M., \& Klein, S. (2018, September 27). In Focus: Reducing Racial Disparities in Health Care by Confronting Racism. The Commonwealth https://www.commonwealthfund.org/publications/newsletter-article/2018/sep/focus-reducing-racialdisparities-health-care-confronting.

Jamil, K. et al. (2008). Disparities in Self-Reported Diabetes Mellitus among Arab, Chaldean, and Black Americans in Southeast Michigan. Journal of Immigrant and Minority Health, 10, 397-408. https://link.springer.com/article/10.1007/s10903-007-9108-0.

Janghorbani et al. (2017, November 11). Risk of Diabetes According to the Metabolic Health Status and Degree of Obesity. Diabetes and Metabolic Syndrome, 11 Suppl. 1:S439-S444. doi: 10.1016/j.dsx.2017.03.032. https://pubmed.ncbi.nlm.nih.gov/28404516/.

Kim, D. D., \& Basu, A. (2016). Estimating the Medical Care Costs of Obesity in the United States: Systematic Review, Meta-Analysis, and Empirical Analysis. Value in Health, 19(5), 602-613. https://www.sciencedirect.com/science/article/pii/S1098301516000553. 
Kochanek et al. (2019). Deaths: Final Data for 2017. U.S. Department of Health and Human Services. Centers for Disease Control and Prevention. National Center for Health Statistics. National Vital Statistics Reports. https://www.cdc.gov/nchs/data/nvsr/nvsr68/nvsr68_09-508.pdf.

Ko, E. M. et al. (2014). The Complex Triad of Obesity, Diabetes and Race in Type I and II Endometrial Cancers: Prevalence and Prognostic Significance. Gynecologic Oncology 133(1), 28-32. https://www.sciencedirect.com/science/article/abs/pii/S0090825814000493.

Lambert, J. (2019, March 10). Study Finds Racial Gap Between Who Causes Air Pollution And Who Breathes It. National Public Radio (NPR). https:/www.npr.org/sections/health-shots/2019/03/11/702348935/studyfinds-racial-gap-between-who-causes-air-pollution-and-who-breathes-it.

Lavery, L. A. et al. (1996). Variation in the Incidence and Proportion of Diabetes-related Amputations in Minorities. Diabetes Care, 19(1), 48-52. https://pubmed.ncbi.nlm.nih.gov/8720533/.

Lefebvre, K. M., \& Lavery, L. A. (2011). Disparities in Amputations in Minorities. Clinical Orthopedics and Related Research, 469(7), 1941-1950.

Leitner, D. R. et al. (2017, November). Obesity and Type 2 Diabetes: Two Diseases with a Need for Combined Treatment Strategies - EASO Can Lead the Way. Obesity Facts, 10(5), 483-492. https://www.ncbi.nlm.nih.gov/pmc/articles/PMC5741209/.

Levy, E., Levy, P., \& Basdevant, A. (1995). The Economic Cost of Obesity: the French Situation. International Journal of Obesity and Related Metabolic Disorders: Journal of the International Association for the Study of Obesity, 19(11), 788-792. https://europepmc.org/article/med/8589779.

Link, C. L., \& McKinlay, J.B. (2009). Disparities in the Prevalence of Diabetes: Is it Race/Ethnicity or Socioeconomic Status? Results from the Boston Area Community Health (BACH) Survey. Ethnic Disparity, 19(3), 288-292. https://www.ncbi.nlm.nih.gov/pmc/articles/PMC3706078/.

Lord, J., Roberson, S., \& Odoi, A. (2020). Investigation of Geographic Disparities of Pre-diabetes and Diabetes in Florida. BMC Public Health, 20. https:/www.ncbi.nlm.nih.gov/pmc/articles/PMC7425001/.

Louisiana Department of Environmental Quality. (n.d.). "Air Toxics Monitoring." https://www.deq.louisiana.gov/index.cfm?md=pagebuilder\&tmp=home\&pid=air-toxics-monitoring.

Loureiro, M. L. \& Nayga, R. M. (2005). International Dimensions of Obesity and Overweight Related Problems: An Economics Perspective. American Journal of Agricultural Economics, 87 (5), 1147-1153, https://doi.org/10.1111/j.1467-8276.2005.00800.x. $\quad$ https://academic.oup.com/ajae/articleabstract/87/5/1147/129301.

Margolis, D. J. et al. (2011). Prevalence of Diabetic Foot Ulcer and Lower Extremity Amputation among Medicare Beneficiaries, 2006 to 2008. Data Points \#1. https://www.ncbi.nlm.nih.gov/books/NBK63602/.

. Incidence of Diabetic Foot Ulcer and Lower Extremity Amputation among Medicare Beneficiaries, 2006 to 2008. Data Points \#2. https://www.ncbi.nlm.nih.gov/books/NBK65149/.

Marshall, J. D., Brauer, M., \& Frank, L. D. (2009). Healthy Neighborhoods: Walkability and Air Pollution. Environmental Health Perspectives, 117(11):1752-9. doi: 10.1289/ehp.0900595. https://pubmed.ncbi.nlm.nih.gov/20049128/.

Marley, T. L., \& Metzger, M. W. (2015). A Longitudinal Study of Structural Risk Factors for Obesity and Diabetes Among American Indian Young Adults, 1994-2008. Preventive Chronic Disease, 12:140469. DOI: http://dx.doi.org/10.5888/pcd12.140469external

icon. https://www.cdc.gov/pcd/issues/2015/14_0469.htm.

Mitin, T. et al. (2011). Diabetes Mellitus, Race and the Odds of High Grade Prostate Cancer in Men Treated With Radiation Therapy. The Journal of Urology, 186(6), pp. 2233-2238. https:/www.sciencedirect.com/science/article/abs/pii/S0022534711045022.

Moody-Ayers, et al. (2005). Prevalence and Correlates of Perceived Societal Racism in Older African-American Adults with Type 2 Diabetes Mellitus. Journal of the American Geriatrics Society, 53(12), 2202-2208. https://onlinelibrary.wiley.com/doi/epdf/10.1111/j.1532-5415.2005.00501.x.

Most, R. S., \& Sinnock, P. (1983). The Epidemiology of Lower Extremity Amputations in Diabetic Individuals. Diabetes Care, 6(1), 87-91. https://care.diabetesjournals.org/content/6/1/87.short.

Nardone, A. et al. (2020). Associations between Historical Residential Redlining and Current age-Adjusted Rates of Emergency Department Visits due to Asthma across Eight Cities in California: An Ecological Study. Lancet Planet Health, 4: e24-31. https://www.thelancet.com/action/showPdf?pii=S2542$5196 \% 2819 \% 2930241-4$.

Narres, M. et al. (2017, August 28). Incidence of Lower Extremity Amputations in the Diabetic Compared with the Non-diabetic Population: A Systematic Review. PLOS One. https://www.ncbi.nlm.nih.gov/pmc/articles/PMC5573217/pdf/pone.0182081.pdf.

Nguyen, B.T. et al. (2012). The Effect of Race/Ethnicity on Adverse Perinatal Outcomes among Patients with Gestational Diabetes Mellitus. American Journal of Obstetrics and Gynecology, 207(4), 322.e1322.e6.https://www.sciencedirect.com/science/article/abs/pii/S0002937812006631. 
Newkirk, A. R. (2018, February 28). Trump's EPA Concludes Environmental Racism Is Real. The Atlantic. https://www.theatlantic.com/politics/archive/2018/02/the-trump-administration-finds-that-environmentalracism-is-real/554315/.

Noonan, A.S., Velasco-Mondragon, H.E., \& Wagner, F. A. (2016). Improving the Health of African Americans in the USA: An Overdue Opportunity for Social Justice. Public Health Reviews, 37(12), 1-20. DOI 10.1186/s40985-016-0025-4. https://www.ncbi.nlm.nih.gov/pmc/articles/PMC5810013/pdf/40985_2016_Article_25.pdf.

Northridge, M. E., \& Shepard, P. M. (1997). Environmental Racism and Public Health. American Journal of Public Health, 87(5), 730-32. https://www.ncbi.nlm.nih.gov/pmc/articles/PMC1381040/.

Nwagbara, U. (2020). Rural Hospitals Closures in the United States: Theoretical Impact Analysis on African Americans Health Care Disparity in the South. Public Policy and Administration Research, 10(7), 52-76. https://iiste.org/Journals/index.php/PPAR/article/view/53484.

Olden, K., \& White, S. L. (2005). Health-related Disparities: Influence of Environmental Factors. The Medical Clinics of North America, 89(4), 721-38. https://pubmed.ncbi.nlm.nih.gov/15925646/.

Organization for Economic Cooperation and Development (OECD) (2019). The Heavy Burden of Obesity - The Economics of Prevention. https://www.oecd-ilibrary.org/docserver/67450d67en.pdf? expires $=1600268842 \& \mathrm{id}=\mathrm{id} \&$ accname $=$ guest $\&$ checksum $=\mathrm{C} 063666528 \mathrm{C} 0 \mathrm{EF} 3 \mathrm{FB} 0099 \mathrm{~B} 6 \mathrm{C} 717 \mathrm{E} 9 \mathrm{E}$ BA.

Paisey, R. B. et al. (2018, January). Diabetes-related Major Lower Limb Amputation Incidence is Strongly Related to Diabetic Foot Service Provision and Improves with Enhancement of Services: Peer Review of the South-West of England. Diabetic Medicine, 35(1), 53-62. https://onlinelibrary.wiley.com/doi/full/10.1111/dme.13512.

Pasley, J. (2020, April 9). Inside Louisiana's Horrifying 'Cancer Alley,' an 85-mile Stretch of Pollution and Environmental Racism that's now Dealing with some of the Highest Coronavirus Death Rates in the Country. Business Insider. https://www.businessinsider.com/louisiana-cancer-alley-photos-oil-refinerieschemicals-pollution-2019-11.

Pezzullo, P. C. (2003). Touring "Cancer Alley," Louisiana: Performances of Community and Memory for Environmental Justice. Text and Performance Quarterly, 23(3), $226-252$. https://www.tandfonline.com/doi/abs/10.1080/10462930310001635295.

Piccolo, R.S. (2014). The Contribution of Biogeographical Ancestry and Socioeconomic Status to Racial/Ethnic Disparities in Type 2 Diabetes Mellitus: Results from the Boston Area Community Health Survey. Annals of Epidemiology, 24(9), 648-54. https://pubmed.ncbi.nlm.nih.gov/25088753/.

Piccolo, R.S. et al. (2016, July). Relative Contributions of Socioeconomic, Local Environmental, Psychosocial, Lifestyle/Behavioral, Biophysiological, and Ancestral Factors to Racial/Ethnic Disparities in Type 2 Diabetes. Diabetes Care, 39(7), 1208-17. doi: 10.2337/dc15-2255. https://pubmed.ncbi.nlm.nih.gov/27330127/.

Pinderhughes, R. (1996). The Impact of Race on Environmental Quality: An Empirical and Theoretical Discussion. Sociological Perspectives, 39(2), 231-248. https://www.jstor.org/stable/1389310?seq=1.

Presser, L. (2020, May 19). The Black American Amputation Epidemic. PROPUBLICA. https://features.propublica.org/diabetes-amputations/black-american-amputation-epidemic/.

Rabi, D. M. et al. (2006, October 3). Association of Socio-economic Status with Diabetes Prevalence and Utilization of Diabetes Care Services. BMC Health Services Research, 6 (124). https://pubmed.ncbi.nlm.nih.gov/17018153/.

Rayman, G. et al. (2004). Are We Underestimating Diabetes Related Lower-Extremity Amputation Rates? Diabetes Care, 27(8), 1892-1896. https://care.diabetesjournals.org/content/27/8/1892.full-text.pdf.

Rosenstock, S. et al (2014). Racial Disparities in Diabetes Mortality in the 50 Most Populous US Cities. Journal of Urban Health, 873-885. https://www.ncbi.nlm.nih.gov/pmc/articles/PMC4199450/pdf/11524_2013_Article_9861.pdf.

Rucker-Whitaker, C., Feinglass, J., \& Pearce, W. H. (2003). Explaining Racial Variation in Lower Extremity Amputation: a 5-year Retrospective Claims Data and Medical Record Review at an Urban Teaching Hospital. Archives of Surgery, 138(12), 1347-51. doi: 10.1001/archsurg.138.12.1347. https://pubmed.ncbi.nlm.nih.gov/14662537/.

Sampson, R. J., \& Winter, A. S. (2016). The Racial Ecology of Lead Poisoning. Du Bois Review, 1-23. https://scholar.harvard.edu/files/alixwinter/files/sampson_winter_2016.pdf.

Satcher, D. (2020). My Quest for Health Equity. Baltimore, MD: Johns Hopkins University Press.

Saydah, S. et al. (2017). Disparities in Diabetes Deaths Among Children and Adolescents — United States, 2000-2014. CDC. Morbidity and Mortality Weekly Report, 66(19), 502-505. https:/www.ncbi.nlm.nih.gov/pmc/articles/PMC5657647/. 
Scott, A. J., \& Wilson, R.F. (2011). Social Determinants of Health among African Americans in a Rural Community in the Deep South: An Ecological Exploration. Rural Remote Health, 11(1), 1634. https://www.ncbi.nlm.nih.gov/pubmed/21299335.

Signorello, L.B. et al. (2007). Comparing Diabetes Prevalence Between African Americans and Whites of Similar Socioeconomic Status. American Journal of Public Health, 97(12), 2260-2267. https://www.ncbi.nlm.nih.gov/pmc/articles/PMC2089102/.

Spanakis, E. K., \& Golden, S. H. (2013). Race/Ethnic Difference in Diabetes and Diabetic Complications. Current Diabetes Reports, 13(6), 10.1007/s11892-013-0421-9. https:/www.ncbi.nlm.nih.gov/pmc/articles/PMC3830901/.

Stamatakis, E., Wardle, J., \& Cole, T. J. (2010). Childhood Obesity and Overweight Prevalence Trends in England: Evidence for Growing Socioeconomic Disparities. International Journal of Obesity, 34, 41-47. https://www.nature.com/articles/ijo2009217.

Sridar, S.B. et al. (2016). Risk of Large-for-Gestational-Age Newborns in Women With Gestational Diabetes by Race and Ethnicity and Body Mass Index Categories. Obstetrics Gynecology, 121(6), 1255-1262. https://www.ncbi.nlm.nih.gov/pmc/articles/PMC5079180/.

Tajik, S. et al. (2019, October 24). Risk of Type 2 Diabetes in Metabolically Healthy People in Different Categories of Body Mass Index: an Updated Network Meta-analysis of Prospective Cohort Studies. Journal of Cardiovascular and Thoracic Research, 11(4), 254-263. doi: 10.15171/jcvtr.2019.43. https://pubmed.ncbi.nlm.nih.gov/31824606/.

Tan, T. W. et al. (2019, February 4). Disparities in Outcomes of Patients Admitted with Diabetic Foot Infections. PLoS One, 14(2):e0211481. doi: 10.1371/journal.pone.0211481. eCollection 2019. https://pubmed.ncbi.nlm.nih.gov/30716108/.

Taylor, D. E. (2014). Environmental Racism, Industrial Pollution, and Residential Mobility. New York and London: New York University Press.

Tessum, C. W. et al. (2019, March 26). Inequity in Consumption of Goods and Services Adds to Racial-Ethnic Disparities in Air Pollution Exposure. Proceedings of the National Academy of Sciences of the United States of America (PNAS), 116(13), 6001-6006. https://www.pnas.org/content/pnas/116/13/6001.full.pdf.

Tikkanen, R. (2020, June 5). International Health Care System Profiles - United States. The Commonwealth Fund. https://www.commonwealthfund.org/international-health-policy-center/countries/united-states.

Tull, E. S., \& Chambers, E. C. (2001). Internalized Racism Is Associated With Glucose Intolerance Among Black Americans in the U.S. Virgin Islands. Diabetes Care, 24(8), p. 1498. https:/care.diabetesjournals.org/content/diacare/24/8/1498.1.full.pdf.

Union of Concerned Scientists. (2019, June 21). Inequitable Exposure to Air Pollution from Vehicles in the Northeast and Mid-Atlantic. https://www.ucsusa.org/resources/inequitable-exposure-air-pollution-vehicles.

U.S. Centers for Disease Control and Prevention. (n.d). What is Diabetes? https://www.cdc.gov/diabetes/basics/diabetes.html. . (n.d). Addressing Health Disparities in Diabetes. https://www.cdc.gov/diabetes/disparities.html. . (2007, November 16). Racial Disparities in Diabetes Mortality among Persons Aged 1-19 Years-United States, 1979-2004. Morbidity and Mortality Weekly Report, 56(14), 1184-7. https://pubmed.ncbi.nlm.nih.gov/18004236/.

. (2020, June). Age-Adjusted Cancer Death Rates, All Types of Cancer, Male and Female, United States, 2013-2017. https://gis.cdc.gov/Cancer/USCS/DataViz.html. (2020, June). Leading Cancer Cases and Deaths, All Races/Ethnicities, Male and Female, 2017. https://gis.cdc.gov/Cancer/USCS/DataViz.html.

U. S. Environmental Protection Agency. (2007, August). Fact Sheet. "Diabetes and Environmental Hazards."https://www.epa.gov/sites/production/files/2015-08/documents/deh_english_100-f-07-020.pdf. . (2019, section 12.5.4.). Federal Register, vol. 85, no. 84, Thursday, April 30, 2020, p. 24114. https://www.govinfo.gov/content/pkg/FR-2020-04-30/pdf/2020-08143.pdf.

2019, p. 12-38. Federal Register, vol. 85, no. 84, Thursday, April 30, 2020, p. 24114. https://www.govinfo.gov/content/pkg/FR-2020-04-30/pdf/2020-08143.pdf.

Wachtel, M.S. (2005). Family Poverty Accounts for Differences in Lower-Extremity Amputation Rates of Minorities 50 Years Old or More with Diabetes. Journal of the National Medical Association, 97(3), 334338.https://www.ncbi.nlm.nih.gov/pmc/articles/PMC2568625/pdf/jnma00184-0024.pdf.

Wagner, J. A. (2011). Beliefs About Racism and Health Among African American Women With Diabetes: A Qualitative Study. Journal of the National Medical Association, 103(3), 224-233. https://www.sciencedirect.com/science/article/abs/pii/S0027968415302984.

Williams, M. (2020, June 17). Racism is a Public Health Issue. The Economist. https://eiuperspectives.economist.com/healthcare/racism-public-health-issue. 
Wong, M.D. et al. (2002, November 14). Contribution of Major Diseases to Disparities in Mortality. New England Journal of Medicine, 347(20), 1585-92. https://pubmed.ncbi.nlm.nih.gov/12432046/.

Wolf, A. M., \& Colditz, G. A. (2012). Current Estimates of the Economic Cost of Obesity in the United States. Obesity Research, 6(2), 97-106. https://onlinelibrary.wiley.com/doi/abs/10.1002/j.15508528.1998.tb00322.x.

(1994). The Cost of Obesity. PharmacoEconomics 5, 34-37. https://link.springer.com/article/10.2165/00019053-199400051-00007.

World Health Organization. (2016). Global Report on Diabetes. https://apps.who.int/iris/bitstream/handle/10665/204871/9789241565257_eng.pdf;jsessionid=BFD3A96E32 3AF50E98E5CF589C40DAD6? sequence $=1$.

(2020, April 1). Obesity and Overweight. Key Facts. https://www.who.int/news-room/factsheets/detail/obesity-and-overweight.

(2020, June 8). Diabetes. Key Facts. https://www.who.int/news-room/fact-sheets/detail/diabetes.

(2012, October). Fact Sheet. Diabetes. Quick Facts. https://www.who.int/docs/defaultsource/searo/nde/sde-diabetes-fs.pdf?sfvrsn=7e6d411c 2.

(2018, May 2). Ambient (outdoor) Air Pollution. https://www.who.int/en/news-room/factsheets/detail/ambient-(outdoor)-air-quality-and-health.

. (2016). Preventing Disease through Healthy Environments: A Global Assessment of the Burden of Disease from Environmental Risks.

. (n.d). Environmental Health. https://www.who.int/health-topics/environmental-health\#tab=tab 2.

Wrobel, J. S., Mayfield, J. A., \& Reiber, G. E. (2001). Geographic Variation of Lower Extremity Major Amputation in Individuals With and Without Diabetes in the Medicare Population. Diabetes Care, 24(5), 860-864. https://care.diabetesjournals.org/content/24/5/860.full-text.pdf.

$\mathrm{Xu}$, J. et al. (2020). Mortality in the United States, 2018. National Center for Health Statistics. Data Brief No. 355. https://www.cdc.gov/nchs/data/databriefs/db355-h.pdf.

Zaitoun, A. et al. (2017). The Association of Race with Quality of Health in Peripheral Artery Disease following Peripheral Vascular Intervention: The Q-PAD Study. Vascular Medicine, 22(6), 498-504. https://journals.sagepub.com/doi/full/10.1177/1358863X17733065. 